

\section{Elites, coclizões e Desenvolvimentos. Análise sobre a trajetória recente do Brasil $^{1}$}

\section{Elites, Coalitions and Development. Analysis of recent braziliaa trajectory}

* Flavio Gaitón

${ }^{* *}$ Renato Boschi

\section{Resumo}

Este trabalho visa analisar o papel dos atores estratégicos e das coalizões sociopolíticas na formulação de um projeto de desenvolvimento socioeconômico, definido como um processo de transformação qualitativa da estrutura produtiva, com aumento do bem-estar geral e mudanças da estrutura da sociedade. Utilizando a literatura que relaciona o papel das coalizões e o desenvolvimento, focamos na trajetória recente do Brasil.

Palavras chave: Elites, Coalizões, Desenvolvimento, Brasil.

\section{Abstract}

This paper aims to analyze the role of strategic actors and socio-political coalitions in the formulation of a model of social and economic development, defined as a process of qualitative transformation of the productive structure, with an increase in social welfare. Using the theoretical contributions of literature on role of coalitions and development, we focus on the recent trajectory of Brazil.

Keywords: Elites, Coalitions, Development, Brazil.

\footnotetext{
*Doutor em Ciência Política, IESP/UERJ. Professor adjunto do Instituto Latino-americano de Economia, Sociedade e Política, UNILA. Pesquisador INCT/PPED. 


\section{Introdução}

Este trabalho visa analisar o papel dos atores estratégicos e das coalizões sociopolíticas na formulação de um projeto de desenvolvimento socioeconômico, definido como um processo de transformação qualitativa da estrutura produtiva, com aumento do bem-estar geral e mudanças da estrutura da sociedade.

Após um declínio pronunciado durante o período neoliberal, a literatura sobre desenvolvimento econômico e social revitalizou-se a partir de uma dinâmica convergente entre a crise das experiências orientadas pelo denominado Consenso de Washington, a chegada ao poder de partidos e coalizões identificadas pela rejeição ao neoliberalismo e a discussão acadêmica produzida no campo da economia política comparada, em particular sobre a agenda neodesenvolvimentista (Evans, 1996; Amable, 2003; Ebenau et al. 2015; Boschi, 2011; Gaitán, 2014; Boschi \& Gaitán, 2008; Bresser-Pereira, 2007; Bresser-Pereira, 2010; De Paula, 2007; Boschi \& Gaitán, 2013; Sicsú \& Michel, 2005; De Paula \& Oreiro, 2009; Nogueira da Costa, 2016; Diniz \& Gaitán, 2016; Bértola \& Ocampo, 2012). No caso específico do Brasil, a discussão sobre o novodesenvolvimentismo, ou social-desenvolvimentismo, está ligada a uma conjuntura particular representada por uma transição política que levou ao poder uma coalizão liderada por um partido de base trabalhista.

A análise do caso brasileiro é paradigmática por uma série de razões. Em primeiro lugar, desde o período posterior às bases da república velha o Estado foi bemsucedido em articular uma modalidade de desenvolvimento baseada na indústria como motor de crescimento. A atuação do setor público foi não apenas o ator chave da industrialização, mas também o elemento articulador da sociedade nacional (Boschi, 2011; Diniz, 1978; Sallum Jr., 1999; Perissinotto, 2014). Em segundo lugar, desde a reconquista democrática em meados dos anos 1980, a trajetória econômica se caracterizou pela instabilidade, associada a um longo ciclo de crises e crescimento inserido numa dupla dinâmica de transição: de um lado, de um modelo de economia protegida para outro neoliberal; de outro, da experiência neoliberal para um intento de recuperar o desenvolvimentismo liderado pelo Estado. Por fim, a maneira como foi interrompida a experiência de governo do PT e o seu projeto socioeconômico chama atenção para a capacidade de agência dos diferentes atores envolvidos no ciclo de políticas públicas, em particular aqueles dos campos político e econômico.

O trabalho está organizado em três seções. Na primeira, apresentamos brevemente a discussão sobre desenvolvimento e mudança institucional, focando especificamente no papel das coalizões. A seguir, avaliamos a economia política do pós-neoliberalismo no Brasil, a começar pelo período do presidente Lula (2003-2010) e, depois, a administração da presidente Rousseff (2011-2016). Na terceira seção esboçamos uma análise da crise institucional que acabou com o impeachment da presidente Rousseff. Por fim, um conjunto de conclusões com o intuito de apresentar uma agenda de pesquisa a ser consolidada. 


\section{Estado, Atores predominantes e Coalizōes Desenvolvimentistas}

Desde a conformação da economia do desenvolvimento como campo específico de conhecimento, o Estado ocupou o papel de ator chave na geração de condições institucionais para o crescimento econômico sustentável. A teoria da modernização e a visão alternativa do estruturalismo cepalino consideravam o Estado o ator com capacidade de articular a acumulação de capitais e capacidades consideradas necessárias para o desenvolvimento. Na prática, significava que o Estado devia ocupar um papel chave, não apenas regulando o mercado, mas atuando também na órbita da produção de bens e oferta de serviços. Essas ideias influenciaram os governos da periferia capitalista. Na América Latina, de diferentes maneiras, os governos nacionais levaram a cabo esforços de planejar a atividade dos setores produtivos, visando uma transição de atividades primário exportadoras para outras relacionadas com a indústria. Todavia, o declínio do modelo de substituição de importações e diferentes fatores externos ${ }^{2}$ debilitaram o poder interventor do Estado.

À crise econômica e à capacidade do Estado para contorná-la seguiu-se um descrédito das ideias desenvolvimentistas. A nova direita combinada com o poder dos mercados financeiros, dos organismos multilaterais de crédito e os governos dos países centrais contribuíram para gerar uma zeitgeist que salientava o mercado como alavanca principal do desenvolvimento. Todavia, nos anos 1980, com o intuito de gerar um pensamento alternativo à predominância das visões eurocêntricas no paradigma de políticas públicas, uma série de autores tentou "trazer o Estado de volta" (Evans, Rueschmeyer \& Scockpol, 1985). Nesse sentido, diversos estudos sobre o sucesso dos Estados desenvolvimentistas tentaram apresentar os casos de crescimento acelerado das economias do Sudeste Asiático como uma combinação virtuosa entre a capacidade de seguir caminhos autônomos e uma firme intervenção do Estado (Amsden, 2001; Evans, 1996;Wade, 1990; Johnson, 1982;Woo, 1999). O papel do Estado seria reconhecido também, ainda que de modo tardio, pelos organismos multilaterais de crédito (Banco Mundial, 1997; Banco Mundial, 2002), apesar de ser dentro de uma lógica mercado-cêntrica e utilizando conceitos ambíguos como governança e bom governo.

A revitalização do debate sobre desenvolvimento, que havia sido relegado a um segundo plano no período duro da distopia neoliberal, abriu um leque de temas de pesquisa sobre o papel do Estado, do mercado, das instituições políticas e de governo sobre o financiamento público, o regime monetário, as políticas sociais e setoriais (em particular, industriais), os regimes de bem-estar, entre outros (Rodriguez, 2006; Boschi \& Gaitán, 2013; CEPAL, 2010; CEPAL, 2016- Gaitán, 2014). No campo da Ciência Política, a abordagem de Variedades de Capitalismo teve destaque nos últimos quinze anos, impulsionando uma ampla produção sobre modalidades de capitalismo em perspectiva comparada. Uma parte dos trabalhos recentes sobre economia política tem um caráter descritivo, apresentando as características dos regimes produtivos ou de 
bem-estar em termos da distância ou proximidade a categorias de tipo ideal. Ao mesmo tempo, tendem a sobredimensionar o papel "normalizador de comportamentos" das instituições políticas e de governo. Apesar do mérito que representou o fato de negar a existência de uma única modalidade capitalista, essas abordagens carecem do dinamismo necessário para entender mudanças e continuidades. A presente proposta se relaciona com uma tradição de estudos que analisa o caráter sociopolítico das dinâmicas de crescimento e distribuição, enfatizando o papel dos atores e as coalizões para consolidar um processo de desenvolvimento.

Uma série de estudos tem analisado o Estado desenvolvimentista como um tipo particular de aparato, cujas políticas concentraram poder, autonomia, capacidade e legitimidade para moldar e atingir objetivos explícitos de desenvolvimento econômico, seja estabelecendo e promovendo condições de crescimento econômico, seja organizando-as diretamente (Leftwich apud Onuoha, 2008: 20. Apud Van Wyk, 2009: 47). Nas abordagens sobre o Estado desenvolvimentista, o papel dos atores é analisado a partir de perspectivas diferentes. Em um nível estritamente político, essa literatura faz referência ao papel dos partidos ou grupo de interesse. Em um nível macro, tratarse-ia de analisar o papel das coalizões sociopolíticas na consolidação de dinâmicas de crescimento, incluindo a relação entre o Estado e o Mercado, a articulação entre classes e frações de classe, e a motivação dos atores para estabelecer ações coletivas. Perissinoto (2014) analisa três características dos Estados desenvolvimentistas: dimensão contextual, institucional e volitiva, fazendo referência ao papel das elites ou atores estratégicos.

A literatura tende a entender as elites estratégicas como o grupo social que ocupa posições privilegiadas em diferentes campos (Di Caprio, 2012). A princípio, inclui os atores em posição de autoridade pública, os funcionários públicos, os empresários ${ }^{3}$ e os trabalhadores organizados. Em certos contextos, outros atores podem adquirir protagonismo (exército, líderes religiosos, organizações não governamentais, imprensa, intelectuais). Solimano \& Avanzini (2012) diferenciam três classes de elites: de conhecimento (pessoas que geram e disseminam conhecimento têm uma vantagem especial), entrepeneurial (pessoas com habilidades especiais para criar riqueza, mobilizar recursos e inovar, agentes centrais no processo de crescimento e desenvolvimento) e políticas (com grande impacto na governança através do estabelecimento de consenso político).

As elites ocupam um papel estratégico na consolidação de uma dinâmica de desenvolvimento. Em primeiro lugar, as elites ocupam uma posição chave no processo de produção de políticas públicas. Por outro lado, elas têm uma posição privilegiada na formação e redefinição das instituições políticas e de governo (Leftwich \& Hogg, 2011). Além disso, podem favorecer a produtividade e competitividade do regime produtivo, seja diretamente por meio do investimento (como as elites econômicas ou o próprio Estado), seja definindo as regras sobre que é permitido ou não. 
A literatura enfatiza, de modo distinto, a relação entre atores predominantes e o desenvolvimento. Hancké, Rhodes e Thatcher (2007) destacam o papel das coalizões, das classes e dos interesses, a fim de compreender as dinâmicas particulares das diferentes economias políticas com matrizes institucionais distintas. Em sentido semelhante, Leftwich \& Hogg (2011) consideram o desenvolvimento um issue de natureza política, e afirmam que o sucesso de uma dinâmica de desenvolvimento depende de processos políticos que envolvam diferentes líderes e elites representativas de grupos, organizações e interesses no momento de ressolver uma série de problemas de comportamento coletivo.

Di Caprio, que define as elites como "um grupo distinto na sociedade com um status privilegiado capaz de exercitar o controle decisivo sobre a organização da sociedade" (2012: 4), afirma que o impacto das elites no desenvolvimento deriva do seu pervasiveness no interior das sociedades e que há problemas para sua análise. Em primero lugar, como defini-las. Em segundo lugar, entender os canais pelos quais as elites exercem influência e, também, como comprometer as elites com os objetivos do desenvolvimento nacional, tendo em conta que as coalizões (de governo e sociopolíticas) não necesariamente são desenvolvimentistas ou orientadas ao crescimento.

Uma série de elementos são recuperados no momento de analisar o papel dos atores estratégicos e as coalizões socioeconômicas no desenvolvimento. O tema da captura - típico do que Evans (1996) chama de Estados predatórios - é um elemento central. Uma vertente da literatura afirma que, em contextos nos quais as elites foram capazes de atingir cooperação e superar o rent-seeking, houve maior prosperidade econômica (Schneider \& Maxfield, 1997). Em certos contextos, atores predominantes e coalizões podem ser efetivos em usufruir recursos públicos de modo predatório, solapando o crescimento sustentável e a inclusão social. As coalizões serão desenvolvimentistas nos casos em que os atores predominantes forem capazes de produzir uma sinergia positiva entre os setores público e privado, com capacidade de implementar políticas públicas como parte de uma agenda de crescimento e distribuição, bloqueando projetos alternativos (Leftwich \& Hogg, 2011).

A capacidade do sistema político para fazer frente às situações de atrito é um segundo tema analisado na literatura. Considerando que há múltiplas alternativas e atores envolvidos no processo de formulação e execução de políticas públicas, é necessário que o aparelho do Estado internalize uma orientação desenvolvimentista em seu funcionamento cotidiano. Isto é mais importante quando se leva em conta a existência de projetos alternativos que podem tentar obstaculizar as medidas do governo. As políticas de desenvolvimento terão apoio e oposições, derivados dos efeitos de sua institucionalização. O dilema é complexo e se relaciona não apenas com a consolidação de coalizões de governo que envolvam atores estratégicos em torno de políticas para o desenvolvimento, mas também em como lograr obstruir projetos alternativos. A formação de uma coalizão de apoio e de consenso em torno de um 
núcleo programático, bem como a sua capacidade de implementação de políticas, são elementos necessários para consolidar uma estratégia de desenvolvimento.

O terceiro elemento é a necessidade de cooperação orientada à consecução de objetivos compartilhados. Uma coalizão pró-crescimento ajuda a solucionar problemas de ação coletiva, facilitando os fluxos de investimento e incrementando a produtividade, ao mesmo tempo que reduz os níveis de incerteza para o setor privado (Peiffer, 2012; Leftwich \& Hogg, 2011; Van Wyk, 2009; Whaites, 2008; Laws, 2012; Leftwich, 2009; Tanaka, 2012; Leftwich \& Laws, 2012). Nesse sentido, Zalanga (2015) afirma que a efetiva formulação e implementação de políticas de desenvolvimento irão depender da chegada ao poder de uma coalizão de governo transformadora (transformative ruling elite coalition) que leve à criação de uma burocracia pública desenvolvimentista. Uma coalizão desse tipo tem o desenvolvimento nacional como sua agenda principal, razão pela qual busca gerar uma organização burocrática que permita realizar os seus objetivos. Em sentido oposto, uma coalizão governante destrutiva (destructive ruling elite) estará mais preocupada em como usar o Estado para acumular poder, riqueza e prestígio para usos pessoais ou particularistas.

Um quarto elemento se relaciona com as comunidades epistêmicas. A literatura especializada salienta que a experiência histórica sobre a implementação bemsucedida de uma agenda de desenvolvimento tem relação também com a conformação de um núcleo de ideias que gerem uma narrativa favorável às iniciativas da coalizão sociopolítica. Em uma chave analítica centrada nos atores, alguns autores salientam a importância das ideias nas dinâmicas socioeconômicas. Em artigo clássico, Hall (1989) afirma que, para se tornarem políticas (policies), as ideias econômicas devem ser viáveis em diferentes aspectos. Em termos econômicos, devem servir para resolver problemas concretos. Em termos políticos, devem expressar uma habilidade, por parte das elites políticas, de execução de suas propostas, o que inclui a formação de alianças ou coalizões. Finalmente, em termos administrativos, que constituem o entendimento dos decision makers sobre as condições efetivas de implementação das políticas derivadas das ideias. Em sentido similar, Erber (2011, p. 53) recupera a importância das convenções de desenvolvimento, definidas como "um dispositivo cognitivo coletivo, composto por conhecimentos codificados e tácitos, que permita hierarquizar problemas e soluções e facilitar a coordenação entre os atores sociais". As convenções de desenvolvimento constituem, assim, dispositivos de identificação e solução de problemas. As abordagens têm o mérito inestimável de reconhecer que as narrativas refletem "...a distribuição de poder econômico e político prevalecente na sociedade num determinado período".

Por fim, é necessário entender em que contexto surgem as coalizões desenvolvimentistas. Uma vertente da literatura afirma que as crises podem atuar como conjunturas críticas que configuram janelas de oportunidade para a formação de coalizões (Peiffer, 2012; Leftwich \& Wheeler, 2011). Assim, para Brautigam, Rakner \& Taylor (2002: 520) uma coalizão pró-crescimento surge quando há uma relação de 
cooperação ativa para atingir políticas que os atores do Estado e o empresariado esperam que impulsione o crescimento e incremente a competitividade. Analisando exaustivamente esta definição, Peiffer (2012) afirma que uma coalizão reformista inclui: i) cooperação ativa entre os atores; ii) organização em torno de uma série de objetivos comuns de um conjunto de políticas reformistas e, iii) as políticas implementadas que são escolhidas para impulsionar o crescimento. Para a consolidação de uma coalizão reformista, a autora considera que deve haver um entendimento comum dos problemas como também incentivos (tanto para o Estado quanto para o empresariado) para trabalhar em uma coalizão.

Considerando a discussão precedente, entendemos uma coalizão desenvolvimentista como a ação sinérgica de um conjunto de atores predominantes, produto de acordos formais e informais, ou de ações convergentes como resultado de uma visão compartilhada sobre a modalidade de desenvolvimento capitalista, baseada na mudança estrutural associada à inovação, investimento produtivo, sustentabilidade e bem-estar. Para ser desenvolvimentista uma coalizão deve ser bemsucedida em uma série de capacidades:

- Formular e implementar políticas públicas que consolidem uma dinâmica de crescimento, inovação e distribuição.

- Contar com a participação cooperativa de atores predominantes dos campos político, econômico e social (em particular, trabalhadores organizados).

- Neutralizar a tendência aos particularismos e a busca de apropriação de rendas dissociada da inovação e o aumento da competitividade que potenciais atores puderem ter.

- Ser bem-sucedida em estabelecer uma narrativa que estruture políticas públicas e mobilize atores de apóio.

\section{Economia Política do pós-neoliberalismo no Brasil}

A economia política do Brasil democrático está marcada pela instabilidade nos anos 1980 e a consolidação de uma modalidade de desenvolvimento próxima das ideias neoliberais, durante os anos 1990. Superada a proposta de levar adiante uma ampla reforma estrutural ortodoxa do Estado e da economia, sob a liderança de Fernando Collor (1989-1992), Fernando Henrique Cardoso 4 logrou estruturar uma coalizão, com o respaldo de atores políticos e econômicos, contando com o apoio popular oriundo da legitimidade obtida após o sucesso do Plano Real para conter a inflação. O projeto do presidente Cardoso procurou superar a Era Vargas por considerá-la fator de retardo do avanço da sociedade. Para isso, ancorou-se nas privatizações, perda do poder das empresas públicas e da capacidade regulatória do Estado, ajuste fiscal, câmbio fixo e sobrevalorizado, políticas sociais focalizadas e compensatórias e uma profunda reestruturação do sistema econômico nacional, expressado em um menor peso da indústria e um avanço da agricultura e do setor financeiro (Diniz, 2007; Diniz \& 
Boschi, 2007; Diniz \& Boschi, 2011; Sallum Jr., 1999). O projeto neoliberal começou a se esgotar na segunda metade dos anos 1990, apresentando baixas taxas de crescimento e uma ruptura da coalizão de apoio. Nesse cenário, houve uma fratura por cima e por baixo da estrutura social que abriu janelas de oportunidade para uma alternância com a chegada ao poder de um partido de base trabalhista. As entidades representativas do empresariado industrial criticaram a "supremacia financeira" do governo, a abertura comercial e a política de juros (Diniz \& Boschi, 2011). Os setores populares se afastaram do governo por causa do crescente desemprego (na casa do 15\% nos últimos anos do governo $\mathrm{FHC}$ ) e da delicada situação social, apesar dos programas de políticas sociais condicionados.

A perda de apoio do empresariado à coalizão neoliberal contribuiu para aprofundar demandas por um novo modelo de desenvolvimento. A vitória eleitoral da frente liderada por Luiz Inácio Lula da Silva ${ }^{5}$, em sua quarta tentativa, representou a chegada à presidência de um partido de base trabalhista. No entanto, a coalizão do presidente Lula foi altamente fragmentada e constituiu-se de partidos políticos tanto de direita (PTB, PL, PP) quanto de esquerda (PCdoB, PSB). A particular combinação de eleição direta de presidente e sistema proporcional com lista aberta para os representantes na Câmara de Deputados acaba gerando uma fragmentação do sistema partidário e forçando uma conformação de alianças com agremiações políticas distintas do ponto de vista do espectro ideológico e programático para garantir maiorias parlamentares, visando a governabilidade.

Todavia, antes da vitória eleitoral de Lula, a medida que o candidato crescia nas pesquisas de intenção de voto, houve fuga de divisas, aumento do valor do dólar e do risco país e queda do valor das ações da bolsa. A desconfiança de diferentes setores do empresariado frente a uma hipotética vitória eleitoral do Partido dos Trabalhadores (doravante PT) levou à coalizão e seu candidato a tomarem medidas para possibilitar a vitória e garantir a transição. A eleição do empresário e senador José Alencar como complemento da chapa encabeçada por Luiz Inácio Lula representou um passo no sentido de estruturar uma aliança entre capital e trabalho (Diniz, 2010; Erber, 2011). Durante a campanha, buscou-se construir uma narrativa que contrastasse a imagem anti-capitalista do PT. Para isso, a Carta ao Povo Brasileiro respaldou o compromisso do candidato com a estabilidade econômica, a responsabilidade fiscal e a segurança jurídica, incluindo os pagamentos a credores internacionais ao mesmo tempo em que defendia um outro modelo de crescimento. Já no governo, foram empossados diferentes ministros oriundos do empresariado, como Roberto Rodrigues (da Associação Brasileira do Agronegócio - ABAG) no Ministério da Agricultura, Luiz Fernando Furlan (presidente do conselho de administração da Sadia) no Ministério do Desenvolvimento, Indústria e Comércio Exterior, Murilo Portugal (Federação Brasileira de Bancos - Febraban) na Secretaria da Fazenda e Henrique Meirelles (Diretor do Fleet Boston Financial Group e deputado eleito pelo PSDB), no Banco Central. 
Por causa da desconfiança dos mercados, a primeira etapa do governo do presidente Lula foi marcada por uma continuidade da política econômica e se caracterizou por uma notória prudência macroeconômica e um modesto crescimento do Produto Interno Bruto (PIB). De fato, os nomes indicados no gabinete econômico expressavam um perfil ortodoxo: Antonio Palocci no Ministério da Fazenda, Joaquim Levy na Secretaria do Tesouro, Marcos Lisboa na Secretaría de Política Econômica, Henrique Meirelles no Banco Central e Murilo Portugal na Secretaría Executiva. O presidente decidiu aumentar o superavit primário para 4,25\% do PIB (maior ainda que a pretensão do Fundo Monetário Internacional) e a taxa de juros da Selic foi aumentada de 25 para 26,5 pontos $^{6}$, além de metas rígidas de inflação. É possível afirmar que os dois primeiros anos de governo Lula expressaram uma dissociação entre os setores mais beneficiados pelas políticas do governo (em particular, a fração financeira do capital) e a base de apoio ideológico da coalizão. De fato, tanto os empresários industriais como os trabalhadores organizados passram a criticar o rumo do governo ${ }^{7}$, atingindo setores internos ao partido do governo ${ }^{8}$.

A política de juros altos para conter a inflação acabou funcionando como fator de coesão de uma aliança tácita entre setores com objetivos antagônicos (burguesia financeira e coalizão de governo formada por partidos de esquerda). O setor financeiro foi um ator chave da coalizão de governo FHC (Diniz e Boschi, 2007; Erber, 2011), período durante o qual passou por uma reestruturação que levou à concentração e maior presença de bancos estrangeiros (Minella, 2007). Já na gestão do PT, o setor se beneficiou da combinação de aumento do consumo doméstico e dos juros altos, como mostra o fato de ter triplicado o volume de lucros líquidos entre 2003 e 2007. Nesse período, sua taxa de lucro passou de 14,8\% em 2003 para 22,9\% em 2007 (Erber, 2011). Em uma perspectiva de longo prazo, os lucros dos bancos, que foram de 34,4 bilhões com Fernando Henrique Cardoso, passaram para 254,9 bilhões com Lula (CONTEC, 2014).

A despeito da importância do setor financeiro, o governo Lula tentou estruturar uma aliança com a burguesia produtiva. Apesar da continuidade macroeconômica, diferentes medidas expressaram uma busca do governo por flexibilizar o caminho neoliberal, entre as quais devem ser salientadas as medidas de caráter social e produtivo. De fato, a administração ampliou a rede de proteção social de modo a universalizar os programas focalizados e apresentou uma série de diretrizes para a política industrial. Produto de um debate com as forças produtivas, a primeira política, a Política Industrial, Tecnológica e de Comércio Exterior (PITCE), lançada em 2004, tentou definir setores prioritários para promover e fortalecer cadeias de valor (fármacos, semicondutores, bens de capital, maquinarias). De Toni (2015) afirma que a política foi ressultado de três vetores simultâneos: o compromisso de campanha do presidente de retomar políticas pró-ativas de desenvolvimento e cooperação intra-governamental, complementadas pela presença de acadêmicos e pelo protagonismo político do próprio presidente, com 
atuação do CNDI (Conselho Nacional de Desenvolvimento Industrial) - órgão criado para promover um diálogo fluido entre setor público, empresários e trabalhadores.

A estratégia de formular um modelo de desenvolvimento baseado no consumo interno como motor de promoção industrial foi se consolidando paulatinamente. De fato, o crescimento a partir de 2004 foi possível por uma combinação de aumento no preço das commodities (um verdadeiro bonus representado pela reversão da deterioração dos termos de troca derivado da demanda global) e a expansão do consumo doméstico. Nesse sentido, podem ser identificados dois momentos que representaram pontos de inflexão na estratégia de articular uma aliança com setores do empresariado nacional. Em 2006 ${ }^{9}$, o presidente decidiu uma mudança de nomes no gabinete, indicando Guido Mantega no Ministério da Fazenda e Dilma Rousseff na Casa Civil (Erber, 2011; Diniz \& Boschi, 2011; Singer, 2012). A saída do Ministro Palocci representou uma derrota dos defensores da ortodoxia financeira ${ }^{10}$ e um avanço dos atores comprometidos com uma estratégia desenvolvimentista.

A nova equipe econômica teve uma maior preocupação pela taxa de câmbio que mostrou uma valorização em relação ao dolar entre 2006 e 2008, o que ampliou o poder de compra das famílias e barateou os bens de capital, gerando aumento do consumo e do investimento privados. Em segundo lugar, houve decisão de aumentar o investimento público. Foi adotada uma série de medidas de caráter desenvolvimentista, de modo a acelerar um modelo puxado pela demanda interna, tentando impulsionar um círculo virtuoso entre produção e consumo de massas (Bielschowsky, 2012). A visão produtivista se reforçou com o anuncio, em janeiro de 2007, do PAC (Programa de Aceleração do Crescimento) que consistiu em um programa de estímulos à indústria e com previsão de investimentos superiores a 4\% do PIB (500 bilhões de dólares) para o período 2007-2010 em matéria de infraestrutura, habitação, transporte, energia e recursos hídricos. Por outro lado, houve uma expansão pronunciada do montante de recursos públicos para financiar a atividade produtiva, através dos bancos públicos (em particular, o Banco Nacional de Desenvolvimento Econômico e Social - BNDES). Por fim, houve medidas para impulsionar o consumo doméstico, o qual ficou em patamares elevados. De fato, O consumo privado cresceu 3,8\% em 2003 e 4,5\% em 2004 e 2005, aumentado para 5,2\% em 2006 e 6,1\% em 2007, caindo levemente para $5,7 \%$ em 2008.

O impulso ao projeto desenvolvimentista teve impacto na expansão sinérgica do consumo e do investimento. Barbosa (2013) afirma que o consumo das famílias cresceu $6,1 \%$ ao ano entre 2006 e 2008, ao tempo que a taxa de investimento ocorreu a uma taxa média de $12,4 \%$ ao ano. A ampliação da demanda doméstica, possível em função da expansão do investimento, possibilitou uma convergência entre capital produtivo e financeiro. A aceleração do crescimento aumentou os lucros e salários num contexto de redução da taxa de juros e gerou uma expansão no crédito, que aumentou de 28\%, em 2005, para 40\% do PIB, em 2008 (Barbosa, 2013). O fato de o setor financeiro ter sido um ator claramente beneficiado pela continuidade da política 
de juros altos não impediu a melhora do setor não financeiro. De fato, produto da combinação de medidas de fomento à produção e aumento do mercado de consumo doméstico, os lucros do setor produtivo superaram os lucros dos bancos. Entre janeiro de 2003 e junho de 2006 a lucratividade dos bancos aumentou 80\%, já a das empresas produtivas o fez $162,4 \%{ }^{11}$.

A crise internacional de 2008 , que impactou no país através da saída de capitais e a menor oferta de crédito para investimento produtivo (De Paula et al. 2013), representou um segundo ponto de inflexão na formulação de uma estratégia de desenvolvimento. A resposta do governo aprofundou o caráter desenvolvimentista, a partir da adoção de uma série de medidas para manter o nível de atividade e emprego, medidas estas que permitiram que o crescimento fosse puxado pelo consumo interno. ${ }^{12}$ Para isso, o governo aprofundou as despesas através de programas públicos (PAC, Minha Casa, Minha Vida), incentivando o financiamento e o consumo doméstico ${ }^{13}$, por meio de uma política de aumento nominal e real do salário mínimo, apoio a exportadores com linhas de crédito e financiamento através do BNDES. O governo flexibilizou as regras para os empréstimos reduzindo os juros, isenções temporais dos tributos a produtos industrializados, como setores como bens de capital, materiais de transporte e materiais de construção (CEPAL, 2012). Houve também um imposto sobre capital externo de curto prazo, além do estabelecimento de licença prévia para importação, a fim de proteger setores como plásticos, alumínio, cobre e ferro, bens de capital, eletrônica, materiais elétricos. Depois da queda de 0,2\% do produto em 2009, houve uma rápida e pronunciada recuperação de 7,5\% em 2010.

De forma gradual, implementou-se uma plataforma de apoio à indústria, a Política de Desenvolvimento Produtivo (PDP), lançada em maio de 2008. O objetivo era coordenar as ações de incentivo do governo ao desenvolvimento industrial do país, com a meta de elevar a taxa de investimento, ampliar a relação entre investimento em P\&D e produto nacional, além de aumentar a participação do país nas exportações mundiais e o número de micro e pequenas empresas exportadoras. O Estado procurou coordenar programas com instrumentos, recursos e responsabilidades bem definidas, com o desafio de outorgar sustentabilidade ao ciclo de expansão, a partir do estabelecimento de metas e políticas. Elaborada sob a supervisão do Ministério do Desenvolvimento, Indústria e Comércio Exterior (MDIC), a PDP foi, de fato, concebida pelo BNDES, principal órgão de fomento às atividades produtivas do país e destacado propulsor da visão desenvolvimentista. Na visão de De Toni (2015), houve avanço em governança instituindo instâncias de coordenação internas do governo federal, protocolos de decisão, instrumentos de monitoramento e avaliação e diferentes ações estruturantes.

O avanço dos setores pró-desenvolvimentistas na coalizão de governo e o maior ativismo estatal para superar a crise expressaram uma busca por consolidar um modelo de desenvolvimento combinando políticas sociais e setoriais, diplomacia empresarial, criação, fortalecimento e ampliação de interfaces público-privadas e uma estratégia 
macroeconômica consistente. Apesar de não contar com apoio para desmantelar radicalmente a estrutura do plano real, o governo foi bem-sucedido em reduzir os juros financeiros. De fato, a taxa Selic caiu entre agosto de 2005 e o mesmo mês de 2007 de 19,75 para 11.25. O Copom decidiu reduções paulatinas da taxa Selic: 19,75\% em agosto de 2005, 18\% em dezembro, 17,25\% em janeiro de 2006, 16,5\% em março, $15,25 \%$ em abril, $14,75 \%$ em julho, $14,25 \%$ em agosto, $13,75 \%$ em outubro, $13,25 \%$ em novembro. Em 2007 continuou a queda: 13\% em janeiro, 12,75\% em março, 12,5\% em abril, 12\% em junho, 11,5\% em julho e 11,25\% em março (Banco Central do Brasil, histórico das taxas de juros).

Pode-se afirmar que nos dois períodos de governo do presidente Lula da Silva a coalizão de governo logrou estruturar coalizões de tipo win-win para os diferentes setores econômicos e sociais. $\mathrm{O}$ aumento no investimento em infraestrutura e financiamento produtivo, do consumo das famílias e das exportações gerou um efeito sinérgico entre consumo residencial e investimentos privados (Erber, 2011; Diniz \& Boschi, 2011; Diniz, 2007). De fato, houve uma articulação virtuosa entre trabalhadores, burguesia industrial, agrária e financeira e pequenos produtores (lanoni, 2013; 2014). Resultado da combinação entre um ambiente externo favorável e um maior ativismo estatal, diferentes setores tiveram algum motivo para ser parte do apoio, mais manifesto ou tênue.

As entidades representativas do setor industrial mantiveram boas relações com o governo, o que gerou uma divisão entre os setores mais críticos (IEDI, CIESP) e os mais próximos ao oficialismo (FIESP, CNI). Em 2007, lideraram um abaixo assinado contra a Contribuição Provisória sobre Movimentação Financeira (CPMF), cobrando desonerações do governo. Skaf, homem forte da FIESP apoiou o Lula nas eleições de 2002. Atritos em torno do patamar da taxa de juros básica (SELIC), do spread bancário, do câmbio, sobre a redução da alíquota para o sistema S, carga tributária, "desperdício" nos gastos públicos e "custo Brasil". Houve apoio crítico, ao lado da reclamação contra a recessão, juros, carga tritubária (com destaque para a campanha contra a CPMF) e legislação trabalhista. Apesar do acompanhamento tácito do presidente da FIESP, o presidente Lula tentou se equilibrar entre os atores, tratando de não depender exclusivamente de uma liderança ou associação em particular.

O setor agropecuário cresceu e se diversificou, aproveitando a maior demanda de produtos naturais que levou a uma valorização do preço das commodities no mercado mundial. A produção de grãos passou de 96 milhões de toneladas, na safra 2001/2002 para 150.8 milhões de toneladas na safra 2013/2014 (MAP, 2012). As exportações passaram de 17 bilhões em 2002 para 63 bilhões em 2010, com um crescimento médio de $11 \%$ anual (Freitas, 2012). A participação do agro brasileiro no comércio mundial passou de 4,6\% em 2002 para 7,3\% em 2009, ressaltando a sua importância estratégica no saldo comercial do país, dado sua participação na pauta de exportações. No entanto, a produção agropecuária se manteve altamente concentrada: as quinhentas maiores empresas do setor tiveram receita líquida de 514 
bilhões de reais, das quais apenas cinquenta concentraram com $60 \%$ do total. ${ }^{14} \mathrm{O}$ setor manteve relações ambíguas com o governo Lula. No início do governo, em 2003, o presidente da CNA, Antonio de Salvo, considerou o ano positivo para a maior parte das atividades da agropecuária brasileira ${ }^{15}$. Em 2005 houve um tratoraço para compensar a perda das safras e garantir o rendimento dos produtores. Em 2006, a CNA criticou a Norma Regulamentadora Rural 31 do MTeE. Em 2009 houve renegociação das dívidas agrícolas por meio de diversas medidas provisórias do governo. Em 2010 as entidades agropecuárias defenderam o empréstimo subsidiado do BNDES. Em geral, apesar das críticas e dos reclamos (em geral, por um novo modelo de financiamento), houve relações cordiais, considerando que as medidas econômicas não contrariaram a rentabilidade do setor. Houve legislação permissiva com o uso de transgênicos, reprogramação de dívidas, plano Safra e afrouxo da legislação ambiental.

Os trabalhadores organizados formaram parte nodal da base de apoio do governo, por diferentes razões. Como afirma lanoni (2013), o PT tem nos assalariados uma base importante, tendo em vista sua proximidade com a Central Única dos Trabalhadores (CUT), o Movimento dos Trabalhadores Rurais Sem Terra (MST) e a Confederação Nacional dos Trabalhadores na Agricultura (Contag). Diferentes medidas do governo consolidaram esse apoio. De um lado, foram aprovadas normas beneficiando os trabalhadores, como a prorrogação de licenças de maternidade, reconhecimento de centrais sindicais e programas para trabalhadores de baixa renda em trabalho doméstico (Moraes, 2013). Em segundo lugar, houve avanço significativo na criação de emprego. Durante os oito anos do governo Lula foram criados mais de 15 milhões de postos de trabalho, dos quais mais de quatro milhões no período pós-crise de $2008 .^{16}$ Apesar de a população economicamente ativa ter passado de 87,7 milhões para 104,7 milhões entre 2000 e 2013, ${ }^{17}$ o desemprego caiu: foi de 7,1\% em 2000 e 11,7\% em 2002, caindo desde a chegada ao poder do PT: 11,5\% em 2004; $10 \%$ em 2006; 7,9\% em 2008 e 6,7\% em 2009. ${ }^{18}$ Em terceiro lugar, houve uma política de valorização real do salário mínimo que ampliou a participação da massa salarial como proporção do PIB de 31,4\% em 2002 para 35,1\% em 2009 (Singer, 2012). O salário mínimo passou de R\$ 200 em 2002 para R\$ 240 em 2003. A melhora foi constante, sempre acima da inflação: R\$ 260 em 2004, R\$ 300 em 2005, R\$ 350 em 2006, R\$ 380 em 2007, R\$ 415 em 2008, R\$ 465 em 2009, R\$ 510 em 2010.

Os aumentos de salário resultaram na superação de um modelo capitalista desligado do consumo para tentar se articular um modelo de produção e consumo de massas. Junto com a criação de emprego privado, houve uma expansão dos concursos públicos e melhora na carreira da União, dinâmica na qual os sindicatos ocuparam um papel ativo. Por fim, houve um aumento da participação dos trabalhadores em canais de intermediação de interesses (Fórum Nacional do Trabalho, Conselho de Desenvolvimento Econômico e Social - CDES, Conselho Nacional de Desenvolvimento Industrial - CNDI). O aumento do salário mínimo se combinou com a expansão de programas sociais ${ }^{19}$ de modo a atenuar o caráter focalizado (Bichir, 2015), o que se 
expressou em uma redução da desigualdade e da pobreza. O programa Fome Zero foi lançado em janeiro de 2003 e o Bolsa Família em outubro (primeiro como MP 132 e logo aprovado por Lei 10836/4). Em julho de 2005 foi implementado o SUAS, Sistema Único de Assistência Social. De fato, os indicadores mostram um declínio da situação de pobreza durante os primeiros anos da gestão do PT (Paes de Barros, 2009; IPEA, 2012). O ciclo de redução de pobreza foi aprofundado. Considerando apenas o período inicial do PT no governo, passou de 36\% para 23\% (Singer, 2012). O gasto em transferência de renda para as famílias passou de 6,8\% do total em 2003 para 9\% em 2010 (Singer, 2012). O Índice de Gini caiu em menor proporção ${ }^{20}$, mas é importante salientar que caiu por uma maior participação dos três decis inferiores.

A expansão econômica garantiu (ou, ao menos, a aquiescência dos empresários organizados) a melhora da renda dos setores populares, concomitante a vantagens para os setores médios (a cotação do dólar barateou as importações e facilitou o consumo interno e no exterior) e consolidou, em sucessivas vitórias eleitorais, a base política do presidente Lula. De fato, o presidente foi bem-sucedido em superar acusações de corrupção que abalaram o primeiro mandato quando, em agosto de 2005, o publicitário Duda Mendonça (quem havia estado relacionado à campanha presidencial do PT em 2002) deu depoimento na CPI dos correios associando a campanha presidencial de 2002 a crimes eleitorais (financiamento irregular de caixa 2). Posteriormente, um esquema de suposta corrupção denunciado por um deputado do PTB que consistia no pagamento a parlamentares em troca de apoio político. O Ministro da Casa Civil, José Dirceu, e o Ministro da Fazenda, Antonio Palloci, foram denunciados como consequência da acusação. Apesar do impacto mediático, a figura presidencial conseguiu contornar a crise e, nas eleições de 2006 o presidente Lula foi reeleito com o apoio do $60 \%$ do eleitorado.

De todo modo, o delicado equilíbrio foi possível dentro de uma dinâmica que respeitava os limites herdados do período neoliberal, conhecido popularmente como tripé econômico: taxa de câmbio valorizado, equilíbrio fiscal e um sistema extremamente rígido de metas de inflação. Assim, a estratégia de combinar aumento de salários com promoção de consumo interno de modo a potencializar a articulação entre políticas econômicas e sociais encontrou um limite na política de moderar o consumo para não gerar pressões inflacionárias e pela oposição do empresariado a algumas medidas. Apesar de algumas iniciativas conjuntas entre empresariado e trabalhadores, a dificuldade para articular uma aliança virtuosa entre setores produtivos e trabalhadores organizados deriva, em parte, da visão ortodoxa do empresariado, que em termos gerais continua demandando medidas próprias de economias abertas. No caso particular do setor agrário, que responde por $15 \%$ do emprego nacional (e, segundo dados da PNAD, tem 60,2\% dos trabalhadores sem carteira assinada), há uma demanda por leis mais flexíveis, como expresso pelas autoridades da CNA em repetidas manifestações públicas. Essa mesma visão acaba entorpecendo relações mais virtuosas entre empresariado e Estado, tendo em vista o consenso do 
setor privado em prol da reforma do aparato estatal (redução da burocracia e o gasto público) e reformas impositivas.

O equilíbrio entre forças políticas e sociais se alterou com a chegada ao governo da presidente Rousseff, ${ }^{21}$ num cenário de fortalecimento da crise internacional. A estratégia inicial de governo consistiu numa combinação de medidas de cunho ortodoxo para conter os riscos de a inflação aumentar. Entre elas estava o corte de gastos (incluindo a suspensão de alguns investimentos públicos), aumento do superávit fiscal primário e elevação de juros. No entanto, não houve descontinuidade de medidas de valorização do salário mínimo e expansão dos gastos sociais. De fato, em junho de 2011 foi anunciado o programa Brasil Sem Miséria. Como resultado, o crescimento caiu de 7,5\% em 2010 para 2,75 em 2011 e apenas 1,03\% em 201222; apesar do qual o desemprego foi reduzido a $6 \%$ e o índice de desigualdade de Gini continuou caindo.

A partir de 2012, o governo tentou implementar uma política econômica marcadamente desenvolvimentista, mostrando uma maior receptividade às queixas dos setores produtivos em relação ao Custo Brasil (Cagnin et al., 2013; Costa Pinto et al., 2016). O conjunto de medidas que o ministro da Fazenda de orientação desenvolvimentista, Nelson Barbosa, denominou de Nova Matriz Econômica visava aumentar as margens para o grau de atuação das empresas privadas (Singer 2015). O pacote de políticas incluía a redução da taxa de juros e o spread bancário, a expansão da oferta de crédito para atividades produtivas, isenções fiscais (inicialmente momentâneas e ad hoc), aplicação de controle de capitais e intervenção no mercado de câmbios a fim de fixar um tipo de câmbio mais competitivo, e reforma do setor elétrico buscando uma redução do preço da energia.

O impacto nocivo sobre a indústria, resultante da combinação de câmbio sobrevalorizado e taxas de juros elevadas, levaram a presidente a promover uma política gradual de redução das taxas de juros, a começar com os bancos públicos. A expectativa era de forçar os bancos privados a imitá-los, com o objetivo de reduzir o diferencial cobrado entre o que os bancos recebem e o que pagam pelos depósitos. Entre agosto de 2011 e outubro de 2012, a taxa básica de juros caiu 5,25 pontos percentuais. De fato, o Comitê de Política Monetária decidiu por sucessivas reduções da taxa Selic entre março e outubro de 2012 e abril de 2013, passando de 10,5\% para 7,25\% (de 10,5\% para 9,75\% em março, 9\% em abril, 8,5\% em maio, $8 \%$ em julho, $7,5 \%$ em agosto, $7,25 \%$ em outubro $)^{23}$. Ao mesmo tempo, o governo promoveu uma depreciação da moeda. A desvalorização do real foi administrada de modo a não descuidar da estabilidade macroeconômica, tendo em conta que a taxa média de inflação passou de 5,8\% nos anos Lula para 6,1\% nos três primeiros anos de Dilma.

A política de redução de juros e a desvalorização cambial abalaram as principais convenções sobre as quais foram erigidas uma estabilidade precária e limitada. A decisão da presidente Rousseff expressou a determinação de reprimir a política de valorização cambial e financeira, dando resposta às demandas dos setores 
produtivos e dos trabalhadores que reclamaram, em repetidas oportunidades, por uma política macroeconômica mais expansiva. Esse conjunto de medidas pode ser entendido como um esforço de acabar com a herança do plano real como única via possível de estabilização macroeconômica, em paralelo a um intento de aprofundar o projeto desenvolvimentista (Barbosa, 2015). A expectativa da coalizão de governo era de produzir um ambiente econômico mais propício para a atividade empresarial que proporcionasse um aumento de investimentos privados. Adotadas de maneira unilateral, produziram inimigos, sem garantir apoios fortes. A redução de juros foi criticada pela Febraban, que exigia medidas compensatórias do governo, gerando um atrito entre o governo e a federação. ${ }^{24}$ A CNI e a FIESP, no entanto, declararam um apoio formal, mas reclamando austeridade nos gastos públicos (CNI) e medidas para aumentar a competitividade do país (FIESP).

Diferentes pressões levaram a flexibilizar essa estratégia. De fato, a presidente acabou incorporando uma agenda ortodoxa na expectativa de criar sinais favo-ráveis aos mercados (em particular, financeiros), a partir da responsabilidade macroeconômica, em especial fiscal (Singer, 2015). Em 2014, o PIB cresceu apenas 0.1\%. Diferentes agências de classificação de risco (Moody's, Stantard \& Poors e Fitch) anunciaram rebaixamentos na situação do país. As empresas de atuação doméstica acabaram acentuando cortes nos investimentos ${ }^{25}$. O processo seria acelerado pela virada conservadora da política da presidenta Rousseff. De fato, logo após as eleições, a presidente anunciou a saída do Nelson Barbosa (que foi transferido para o Ministério de Planejamento) e a pose do Joaquim Levy (ex-Bradesco) no Ministério da Fazenda.

O Copom decidiu aumentar da taxa Selic, que passou de 7,25\% para 7,5\% em abril de 2013. A dinâmica continuou nos meses seguintes: $8 \%$ em maio, 5,8\% em julho, 9\% em agosto, 9,5\% em outubro, 10\% em novembro, 10,5\% em janeiro de 2014, $10,75 \%$ em fevereiro, $11 \%$ em abril. Tendo em vista esses aumentos da taxa Selic, poder-se-ia dizer que a batalha contra o capital financeiro teve como vencedor os bancos. De fato, segundo a CONTEC ${ }^{26}$ (2014), nos três primeiros anos do governo Rousseff as instituições financeiras lucraram 115 bilhões de dólares, com uma taxa média anual de 38 bilhões.

A retração ortodoxa não se esgotou na política de juros. De fato, o governo anunciou um corte de despesas com o objetivo declarado de economizar 1,2\% do PIB para pagar os juros da dívida. Em maio de 2015 foi anunciado um pacto para atingir um maior superávit fiscal, incluindo um corte de 69,9 bilhões de reais, o que atingiu o orçamento do Ministério das Cidades, Saúde, Educação (25,7 bilhões) e Transporte. Também houve aumentos de impostos ou suspensão de medidas de apoio aos setores produtivos. Por fim, cortou direitos trabalhistas ${ }^{27}$. Na expectativa de contar com o apoio do mercado, a presidente Rousseff consolidou um ajuste ortodoxo. No entanto, a resposta não foi a esperada e o governo enfrentou uma série de críticos das políticas adotadas, sem contar com aliados entre os beneficiados. De fato, a medida foi criticada pelas associações industrias como a FIESP e a CNI. - 
Como modo de compensar os empresários, o governo aprofundou as políticas de desonerações fiscais, visando reduzir os custos corporativos. As desonerações ${ }^{28}$ foram introduzias inicialmente em 2008, com o objetivo de conter os impactos da crise capitalista e recuperadas em 2011 no marco do plano Brasil Maior. Anunciado em agosto de 2011, reduzido a um conjunto de setores intensivos em trabalho ou com impacto na apreciação cambial, como têxteis e software. Em 2012 e 2013 foram paulatinamente estendidas a vários setores. Ademais, foram estabelecidas como beneficio permanente na Lei 13.043. O custo fiscal representado pela perda de arrecadação foi crescente. Entre outubro de 2008 e dezembro de 2009 foram R\$ 26 bilhões, em 2010 mais de R\$ 17,5 bilhões. A partir da gestão da presidente Rousseff, as desonerações fiscais mostraram também um paulatino crescimento: $R \$ 3,36$ bilhões em 2011, R\$ 44,8 bilhões em 2012, R\$ 73,7 bilhões em 2013, R\$ 100,6 bilhões em 2014 e R\$ 104,7 bilhões em 2015 (Receita Federal, 2016).

As diferentes medidas do governo não receberam a contrapartida por meio do aumento da taxa de investimento, considerando que esta se manteve $16 \%$ e $17 \%$ do PIB entre 2003 e 2006, aumentando para 18\% em 2007 e $21 \%$ em 2008. A crise gerou uma queda da taxa de investimento em 2009 (18\%), seguida de uma recuperação em 2010 e 2011 (20\%), caindo em 2012 e 2013: 18\%. Assim, houve queda da produção industrial: 3,0\% em 2014 e 8,2\%, em 2015. No setor de bens de consumo duráveis a produção recuou 18,2\% em 2015 e 22,2\% no primeiro semestre de 2016 . No setor de bens de capital a queda foi de $25,4 \%$ em 2015 e de $20,1 \%$ no primeiro semestre de 2016.

Por que a nova matriz econômica fracassou? Uma leva de economistas afirma que houve erros técnicos e de estimação ${ }^{29}$. Ancorados na defesa de uma gestão"previsível e austera" das variáveis macroeconômicas, esses economistas expressam uma crítica ao abandono dos pilares "robustos" do tripé econômico. Nessa visão, a política econômica de estímulos setoriais e intensificação do uso de créditos e repasses promovidos pela presidente Rousseff gerou maior gasto e uma pressão sobre a dívida pública, sem contar com um cálculo razoável da sustentabilidade do aumento. Houve, nesse sentido, erros de estimação da expansão fiscal com juros baixos e câmbio depreciado. A "irresponsabilidade" fiscal combinou-se com sobrepreços, escassa transparência e uma maior "vulnerabilidade à captura". Como ressultado, na visão de alguns críticos da NME, houve menor crescimento, necessidade de aumento de juros, maior inflação e queda da participação dos produtos industrializados. Essas argumentações parecem debilitadas frente às criticas de autores que afirmam que não houve aumento de gastos, mas queda acentuada de despesas durante o governo Dilma, comprometida com o ajuste fiscal (Serrano \& Summa, 2015).

Em outra chave analítica, Singer (2015) afirma que houve uma retaliação de apoio empresarial à presidente, logo após a intenção da presidenta Rousseff de acelerar o viés desenvolvimentista através da ação do Estado, o que teria criado inimigos, fundamentalmente, os bancos, sem contar com o apoio de uma mobilização de 
trabalhadores que sustentasse as mudanças. A presidente Dilma quebrou a regra utilizada pelo predecessor Lula de não confrontar e, como reação, se configurou uma resposta convergente de atores visando acabar com o crescente viés intervencionista do governo.

Em nossa perspectiva, próxima da tese defendida por Singer (2015), houve uma articulação de uma coalizão sociopolítica visando à reorientação das políticas econômicas e um menor nível de intervenção do Estado na atividade privada. A despeito das várias medidas decididas pelo governo, a presidente Rousseff enfrentou um aumento das críticas do empresariado industrial, principalmente pelo baixo crescimento e o risco de desindustrialização. Entrevistas publicadas na imprensa mostram um cansaço do empresariado frente à maior intervenção pública. De um lado, um governo com objetivos desenvolvimentistas tentando "disciplinar" os atores do mercado; de outro, frações da burguesia com poder de veto, reticentes frente às políticas do governo. Se a oposição do setor financeiro ao governo se explica pelo intento (abortado) de reduzir juros e spread bancário, as motivações sobre a resistência do empresariado industrial, tendo em conta o apoio do governo e a proteção implícita da melhora do tipo de câmbio, demandam uma análise.

A motivação do empresariado para não aumentar o investimento pode recair numa combinação de erros de política econômica e ausência de graus de liberdade para faze-lo em virtude do aumento da dívida. Serrano e Summa (2013; 2015) afirmam que houve politcas fiscais e monetárias de contração da demanda a partir de 2010, tomadas em um contexto de desaceleração do investimento privado. A decisão de desacelerar a economia reduzindo o ritmo de crescimento da demanda agregada teve como efeito a queda do aumento do consumo, em particular de bens duráveis. Quando o governo tentou impulsionar novamente o crescimento, optou por uma estrategia de estimulo do investimento através da redução de custos e aumentos na margem de lucro das empresas, e não por aumento da demanda agregada. A expectativa era que, reduzindo os custos ou aumentando a margem de lucro das empresas, haveria investimentos que levariam ao crescimento.

A estrategia de incentivar a iniciativa privada reduzindo os custos ou aumentando a margem de lucro não deu certo e uma explicação pode se encontrar nos graus de liberdade do empresariado para aumentar o investimento. Nesse sentido, Rezende ${ }^{30}$ nega que a crise tenha acontecido por falta de confiança dos investidores. Na sua perspectiva, tratar-se-ia de um problema de endividamento do setor privdo, cuja dívida passou de 35\% do PIB em 2005 para 80\% do PIB em 2015. Numa dinâmica de maior endividamento houve dificuldades para alavancar os investimentos. Isso aconteceu de forma concomitante à queda na valoração de ativos, considerando que o retorno sobre patrimônio caiu entre 2010 e 2016. Assim, as dificuldades do empresariado para investir derivam da insuficiência de fluxos de caixa. Nesse cenário, os recursos que as empresas obtêm são utilisados para reforçar a posição de caixa e 
para refinanciar dívidas con custos menores a prazos mais longos, impossibilitando maiores investimentos.

Os erros de política econômica privilegiando um tipo de desenvolvimentismo mais centrado nos custos e margens das empresas em detrimento do aumento da demanda agregada se combinam com mudanças nos atores econômicos do regime produtivo brasileiro. O próprio perfil da indústria brasileira mudou, com uma ascensão dos setores industriais que processam recursos naturais (Boito, 2009), impulsionado pela chegada do investimento estrangeiro. A participação da indústria de transformação que era de 17,4\% do PIB em 2005 caiu a 15,4\% em 2010 e 9\% em 2015. A reconfiguração da matriz produtiva explica, em parte, porque as medidas não tiveram o impacto anunciado. Como analisado por Mello (2016: 10-11), o perfil de empresariado internacionalizado, dependente de importações e com interesses no rentismo, levariam às políticas industriais a não alcançar os efeitos esperados.

Relacionado com o anterior, deve ser salientada a limitação que representa a configuração do empresariado brasileiro com uma predominância manifesta do capital financeiro. Bruno \& Caffe (2014: 2) afirmam que "a financeirização manifesta-se pela vigência de um padrão de funcionamento das economias, onde a acumulação de riquezas desenvolve-se, preponderantemente, por canais financeiros e não através da revalorização de capitais nas atividades diretamente produtivas, notadamente, na indústria". Na visão dos autores, a financeirização reduz o investimento produtivo e as taxas de crescimento das economias. A poupança produtiva em atividades diretamente produtivas, criando novos ativos é substituída por poupança improdutiva alocada na transferência de propriedade de ativos já existentes. Os juros altos encarecem o custo do dinheiro para financiamento e aumento da produção interna. Os juros altos fazem com que só uma rentabilidade excepcional justifique novos investimentos. Assim, os juros altos acabam atuando como "refúgio" frente ao potencial estancamento. A busca de aplicações rentáveis por parte dos investidores significa que não há um problema de falta de capitais, mas de substituição de investimento produtivo por outro de tipo especulativo.

O processo de financerização acaba atuando como um condicionante para o modo de gestão do Estado. De um lado, está apoiado na dívida pública, que acaba alimentando um circuito de acumulação rentista (Erber, 2011; Bruno \& Caffe, 2014). Erber (2011) afirma que o Estado pagou, em média, quase $6 \%$ do PIB ao ano em juros da dívida durante o período 2003-2009. Dowbor (2015), por sua vez, afirma que: "Abstraindo a dívida pública, os bancos se apropriam de uma carga de juros anuais de $\mathrm{R} \$ 880$ bilhões, $15,4 \%$ do PIB. Uma massa de recursos deste porte transforma a economia (...) esterilizando a dinamização da economia pelo lado da demanda (...) a parte da renda familiar que vai para o pagamento das dívidas passou de $19,3 \%$ em 2005 para 46,5\% em 2015. "

A financeirização no Brasil se relaciona também com a persistência da desigualdade social, atuando como um fator de limitação para aprofundar o tênue (mas contínuo) 
processo de melhora social iniciado em 2002. De um lado, os detentores de títulos conformam um grupo reduzido ${ }^{31}$. Analisando dados publicados pela Secretaria de Política Econômica do Ministério da Fazenda, divulgados no primeiro semestre de 2016 no Relatório da Distribuição Pessoal da Renda e da Riqueza da População 32 Brasileira, Fernando Nogueira da Costa (2015) afirma que: "os números de 2014, declarados pelos contribuintes à RFB em 2015, mostram que o $0,1 \%$ mais rico da população brasileira, ou 27 mil pessoas em um universo de 27 milhões de declarantes do IRPF, afirmaram possuir $\mathrm{R} \$ 44,4$ bilhões em rendimento bruto tributável e $\mathrm{R} \$ 159,7$ bilhões em rendimento total bruto. Eles possuem $6 \%$ da renda bruta e $6 \%$ dos bens e direitos líquidos do país. Essa parcela mais abastada também aufere uma renda $3.101 \%$ superior ao rendimento médio dos declarantes de IRPF e possuem uma quantidade de bens e direitos $6.448 \%$ superior à média". De outro lado, as operações financeiras estão isentas do pagamento de impostos. Como afirmado por Erber (2011), o processo de valorização financeira representa uma transferência de recursos para os setores mais ricos. Altas taxas de juros e isenção de impostos para as operações do setor possibilitam uma transferência de renda, para a alta finança e detentores do capital (Bruno \& Caffe, 2014).

Outro elemento que ajuda a explicar que a resposta às medidas de promoção não foi a esperada é a desnacionalização do complexo produtivo industrial. A desnacionalização ocorre quando uma empresa de capital majoritário estrangeiro adquire, de brasileiros, capital de empresa estabelecida no Brasil. Esse processo foi acelerado através das fusões e aquisições. Em uma fusão, duas (ou mais) empresas viram uma, na aquisição, uma (ou mais) empresas compram outra - ou seja, nas duas operações, sempre ocorre a diminuição de ao menos uma entidade. No período de 2002 a 2015, a velocidade das fusões e aquisições pulou de uma média de 384 em 2002/2005, para 646 em 2006/2009 e, finalmente, para 793 em 2010/2015. Gonçalves (2012) afirma que as 50 maiores empresas em poder de venda por origem de propriedade têm uma constante de desnacionalização em torno do 40 \% (41,9\% em 2009/2010). Considerando as 500 maiores, passou de $43,6 \%$ em 2002 para $41 \%$ em 2010. O processo é expressivo em vários setores mais dinâmicos da economia nacional, como agropecuária, processamento de alimentos e bebidas, mineiração, siderurgia e construção pesada, com uma alta incidência de internacionalização.

A desarticulação da heterogênea coalizão sociopolítica possibilitou uma convergência de atores políticos e certos núcleos empresariais em favor de uma nova estratégia econômica, que acabou na destituição da presidente Rousseff. De fato, as associações do empresariado expressaram o seu respaldo ao processo de impeachment da presidente Rousseff. Os empresários do setor agropecuário maximizaram as suas reivindicações e, em grande número, apoiaram o processo de impeachment ${ }^{33}$, apesar da oposição da ex-presidente da CNA e ministra da Presidente Dilma Rousseff, Kátia Abreu. A FIESP, que pagou uma custosa campanha sobre o Custo Brasil e pediu para "não pagar o pato" foi ativa na defesa da saída da presidente, como 
expressou na campanha Impeachment já. De fato, Paulo Skaf, ator chave da entidade e ligado politicamente ao PMDB, afirmou sem voltas que o governo estava "à deriva", razão pela qual "ou o governo muda e tenta retomar a confiança dos consumidores e dos investidores ou seria melhor arrumar as malas e cair fora." ${ }^{14}$. A CNI não apoiou abertamente o impeachment, mas emitiu comunicados falando de uma situação alarmante, da necessidade de dar um basta. As relações do governo com as entidades industriais foram previamente abaladas pela redução de verbas ao "Sistema S", ocasião na qual o presidente da FIESP Skaf declarou que "iria à guerra", expressando críticas à responsabilidade do governo pela falta de coordenação para a elaboração das políticas industriais, rigidezes da legislação trabalhista e problemas do "custo Brasil".

\section{Atores, convergência de interesses e interrupção da ordem constitucional}

O paulatino e constante afastamento do empresariado em relação ao governo e a radicalização das demandas acentuou a erosão da coalizão de governo e resultou no impeachment e destituição da presidente Rousseff. ${ }^{35}$. Diferentes insucessos foram se somando, levando a uma crise de governabilidade. Em maio de 2015 um movimento chamado Brasil Livre protocolou um pedido de impeachment contra a presidente. Em junho, ela foi acusada de "pedaladas fiscais". No mesmo mês, o presidente da Câmara, Eduardo Cunha, se declarou opositor. Em outubro, o Tribunal de Contas da União recomendou reprovar as contas do governo de 2014 por causa das "pedaladas fiscais"36. Duas semanas mais tarde, parlamentares da oposição entregaram ao presidente da Câmara de Deputados um pedido de impeachment. No início de dezembro, houve uma iniciativa de construir uma comissão investigadora de maneira irregular, recusada pelo Supremo Tribunal. Nos meses seguintes, as iniciativas acabariam dando certo.

A interrupção da gestão presidencial de Dilma Rousseff, em um processo de duvidosa legitimidade, expressa também as dificuldades de consolidar uma coalizão reformista orientada em coordenar o mercado com o objetivo de avançar num projeto desenvolvimentista. O impeachment, apesar de seguir os passos do "devido processo legal" se pareceu bastante a um golpe branco, no qual os deputados e senadores pouco falaram sobre as causas pela qual a presidente estava sendo acusada, e muito das aparentes falências morais da presidente e da coalizão de governo ${ }^{37}$. Assim, com características de profecia auto-cumprida, com uma classe política afastada da presidente e um empresariado engajado numa luta ideológica contra a maior intervenção do poder político, o esforço mais claro de levar a cabo uma política desenvolvimentista acabou em uma saída irregular e ortodoxa; inicialmente, com a derrota do projeto Mantega e a substituição pelo Joaquim Levy e, na sequência, com a formação de uma coalizão claramente mais conservadora, formada por partidos de centro e de direita, e o apoio visível dos empresários. 
O impeachment foi possível pela radicalização das demandas dos atores dos campos político e econômico, cujas agendas foram paulatinamente convergindo, frente à passividade e aquiescência de outros atores do campo societal. Em uma perspectiva de mais longo prazo, o impeachment e destituição da presidente Rousseff podem ser entendidos como o corolário de um conjunto de ações que expressam tanto a radicalização das demandas de atores não incluídos na coalizão sociopolítica quanto a ausência de oposição leal, e também uma incapacidade da presidente e sua coalizão de governo de incorporar e processar demandas e interesses dos diferentes atores estratégicos dos campos político e econômico.

Os embates de uma coalizão opositora ancorada em propostas ortodoxas começaram logo após a reeleição em 2014. Antes da posse do segundo mandato da presidente Rousseff, o candidato derrotado, Aécio Neves (PSDB), gravou um vídeo convocando à população para um protesto. Ao mesmo tempo, o seu partido pediu ao Supremo Tribunal Federal a cassação do registro da chapa Rousseff-Temer e que o candidato derrotado assumisse o cargo de presidente em seu lugar. Em outubro de 2015, o processo solicitado pelo PSDB para anular o mandato da presidenta Rousseff foi reaberto. Nesse março, os protestos acabaram potencializando o oportunismo dos atores do campo político e facilitando as demandas do campo econômico.

A presidente Rousseff foi perdendo graus de manobra para articular uma coalizão política. Reeleita em 2014 com o apoio de 10 partidos, de modo paulatino diferentes lideranças e formações políticas foram se afastando do governo, incluindo alguns partidos de tamanho médio (PSD, PSB, PR, PP, PRB) e outros menores (PMN, PTC, PRTB, PTdoB). A perda de aliados dificultou ainda mais a capacidade de formar maiorias parlamentares para a aprovação de leis ${ }^{38}$, expressa em uma série de derrotas, como o Código Florestal, o Fundo de Participação dos Estados, o Plano Nacional de Participação Social que visava a criação de Conselhos Populares, a proibição de financiamento privado das campanhas eleitorais, a Reforma do Imposto de Circulação de Mercadorias e Serviços, a recusa a aceitar um plebiscito para uma reforma política orientada a responder às demandas dos manifestantes em 2013, a longa discussão sobre a proposta do Executivo de alocar os royalties do pré-sal em educação e saúde, a rejeição do nome escolhido pela presidente para continuar com Diretor Nacional da Agencia de Transportes e a dificuldade para aprovar o orçamento de 2012, entre outras. Em setembro de 2015, a presidente tentou a volta da CPMF e até sua base aliada votou contra. Pode-se afirmar que, no plano estritamente político, a presidente Rousseff foi vítima de uma situação de extremo oportunismo, em que os atores de um sistema partidário brasileiro fragmentado e pouco ideologizado se mostraram incapazes de gerar um esquema de soma positiva.

O epílogo das dificuldades da presidente Rousseff aconteceu no momento da ruptura com o PMDB, partido de filiação do vice-presidente Michel Temer. Em 29 de março, ao grito de "Fora Dilma, Temer Presidente", as lideranças partidárias decidiram se declarar "independentes". Ex-aliados, incluindo antigos ministros da presidenta 
Rousseff, passaram a criticar o rumo do governo e até votaram favoravelmente no processo de impeachment ${ }^{39}$. A relação entre o PT e o PMDB foi também afetada por um desgaste contínuo. Apenas iniciado o segundo mandato, a chefa do Executivo buscou reduzir a dependência de partidos aliados, para o qual tentou, sem sucesso, eleger um deputado do PT como presidente da Câmara, complicando a relação entre ambas formações. As crescentes dificuldades na relação com o Parlamento, o clima de crise política e as demandas (de aliados e opositores) forçaram a presidente a reorganizar a articulação política entre Executivo e Legislativo. Para isso, nomeou o vice-presidente como articulador em substituição de uma figura partidária, decidiu uma redução do número de ministérios (de 39 a 31) e ampliou o poder do principal partido aliado, o PMDB, que passou de 5 a 7 ministros. A medida foi ineficaz e, em numa tentativa de recuperar graus de governabilidade nomeou o ex-presidente Lula na Casa Civil, mas a medida foi impedida por uma decisão da Justiça Federal e acabou acelerando a dinâmica do processo de impeachment.

A própria forma de exercício do poder da presidente Rousseff contribuiu para acelerar a ofensiva opositora. Ela assumiu o combate contra a corrupção como um dos eixos do seu segundo governo. Diferentes medidas, como o veto à lei de financiamento empresarial, o estímulo a leis contra a corrupção, a liberação a Polícia Federal para levar a cabo investigações de crimes por corrupção, "faxinas" em ministérios conduzidos por partidos aliados, ou declarações da presidente sobre corrupção, acabaram sendo mal processadas por lideranças partidárias e podem desempenhado um fator de estímulo de um setor amplo da "classe" política para avançar no impeachment ${ }^{40}$. Por outro lado, o governo e, particularmente, a presidente, desativaram ou desmobilizaram as instâncias de articulação de interesses criadas durante o governo Lula. Por fim, o estilo decisionista tendeu a isolá-la de apoios partidários e aliados e contribuiu para concentrar na sua figura as dificuldades para a retomada do crescimento.

As crescentes dificuldades expressam a incapacidade da presidenta Rousseff de lidar com as demandas e pressões dos atores do sistema político partidário e a ausência de uma oposição leal. Na sua análise da causa da queda das democracias, Linz (1978) utiliza os conceitos de lealdade, semilealdade de deslealdade da oposição em um regime democrático. Sem cair em uma posição naif, reconhece como parte do repertório válido dos partidos buscar desacreditar o governo (ou outros partidos) e buscar apresentá-los como distantes do interesse público. No entanto, é a intensidade e o uso de má fé das condutas que podem ser definidos como oposição desleal. Já Duverger (1980 [1951]) fez referência à oposição sem princípios. A votação do processo de impeachment mostrou também a fragilidade da coalizão do governo. De fato, ex-ministros e lideranças da coalizão votaram a favor do afastamento da presidenta Rousseff. 


\section{Conclusão}

Neste artigo tentamos analisar a trajetória recente do capitalismo brasileiro, centrado no papel dos atores estratégicos e das coalizões para consolidar uma dinâmica de desenvolvimento sustentável. Definimos coalizão desenvolvimentista como a ação convergente de diferentes atores dos campos político, econômico e social para consolidar um conjunto de políticas públicas orientadas ao crescimento sustentável. Analisar as coalizões de desenvolvimento significa enfatizar as motivações por trás da ação dos atores predominantes e a capacidade das coalizões para incentivar práticas de cooperação que sejam bem-sucedidas em promover o crescimento e a distribuição. Sem negar as relações externas e a importância das influências exógenas, o desenvolvimento é uma questão de ordem interna.

Desde a chegada ao poder da frente liderada pelo Partido dos Trabalhadores, houve no Brasil um esforço para recuperar o legado desenvolvimentista, aumentando a participação do Estado por meio da expansão de gastos e aumento de consumo interno e de políticas industriais e sociais. É possível identificar diferentes coalizões em variados temas, contextos e cenários. Assim, houve coalizões relativamente fáceis do tipo win-win em alguns períodos, em particular nas administrações Lula, e outras mais difíceis de implementar pelo simples fato de impor perdas (ou tentar fazê-lo) a algum grupo social. Todavia, o projeto de Lula foi se moldando de modo a não alterar os pilares do Plano Real (na expectativa de considerar a estabilidade um "valor" da sociedade), em um delicado equilíbrio entre mudança e continuidade. Assim, o imperativo de não ultrapassar os limites da "responsabilidade" macroeconômica acabou definindo os limites das políticas de intervenção do Estado.

O maior viés intervencionista do governo Lula encontrou limites na conformação de um modelo de "conciliação" entre Estado e empresariado. A política rígida e ortodoxa de metas de inflação costuma ser matizada com a narrativa que estabelece que os "pobres" tendem a ser os mais prejudicados em períodos de alta inflação (Erber, 2011). No entanto, representou uma maciça transferência de recursos que acabou influenciando a estrutura produtiva e impedindo o aprofundamento de uma nova política econômica. Quando, já no período Rousseff, o governo tentou ampliar o grau de intervenção pública sobre a atividade privada houve uma desarticulação da aliança tênue, pouco estruturada, com as diferentes frações do capital. De fato, houve oposição das diferentes frações do capital e não foi possível manter a taxa de investimento.

A existência de uma coalizão não implica ausência de conflitos, nem permanência de uma configuração estática, mas sim certa aliança (expressa ou tácita) para orientar objetivos de políticas públicas. Para isso, uma coalizão desenvolvimentista deve mostrar capacidade em um conjunto de arenas: de um lado, deve ser bem-sucedida em orientar os atores de modo a irem além das práticas de curto prazo e meramente ricardianas; de outro, deve ter habilidade para impedir o surgimento de coalizões antidesenvolvimentistas ou neutralizar as suas estratégias. 
Diversos autores têm analisado que o modo de produção capitalista gera uma "dependência estrutural do Estado com relação ao capital" (Przeworski \& e Wallerstein, 1988), derivada das múltiplas funções do setor privado, incluindo ações "vitais para o normal funcionamento de um modelo econômico" (Offe, 1985). De outro lado, as decisões de investimento não estão sujeitas ao controle democrático (Lindblom, 1982). O empresariado constitui um ator fundamental e, não menos importante, um ator estratégico que busca influenciar no ciclo de políticas públicas, seja individualmente ou por meio de organizações empresariais. Aos empresários depende a decisão de investir ou não (chegando, em casos extremos, ao lock out ou até ao fechamento da empresa), contratar mão de obra, capacitá-la e, sobretudo, inovar (Schumpeter, 1984).

A situação das diferentes frações do capital, apesar de não ser homogênea, foi efetiva em se consolidar de modo convergente. O agronegócio, o capital financeiro e a indústria convergiram na demanda de reduzir o tamanho do Estado, a carga fiscal (não "pagar o pato") e reformar as leis trabalhistas ${ }^{41}$. Frente à oposição empresarial, o campo político se mostrou desarticulado e ineficaz. Sem apoio político interno e assediada por setores extremamente conservadores, a presidente Dilma foi perdendo paulatinamente poder de manobra (desde demitir um ministro desenvolvimentista e substituí-lo por um outro ortodoxo até vetar leis trabalhistas). Todavia, não houve reação positiva dos setores empresariais nem solução de compromisso. Para explicar as causas, costuma ser mencionado desde características da burguesia nacional, profunda instabilidade que leva aos empresários a ter estratégias de busca de rendas de privilégios (como o crescimento de atividades rentistas da burguesia industrial) e as diferentes estratégias de uma intervenção.

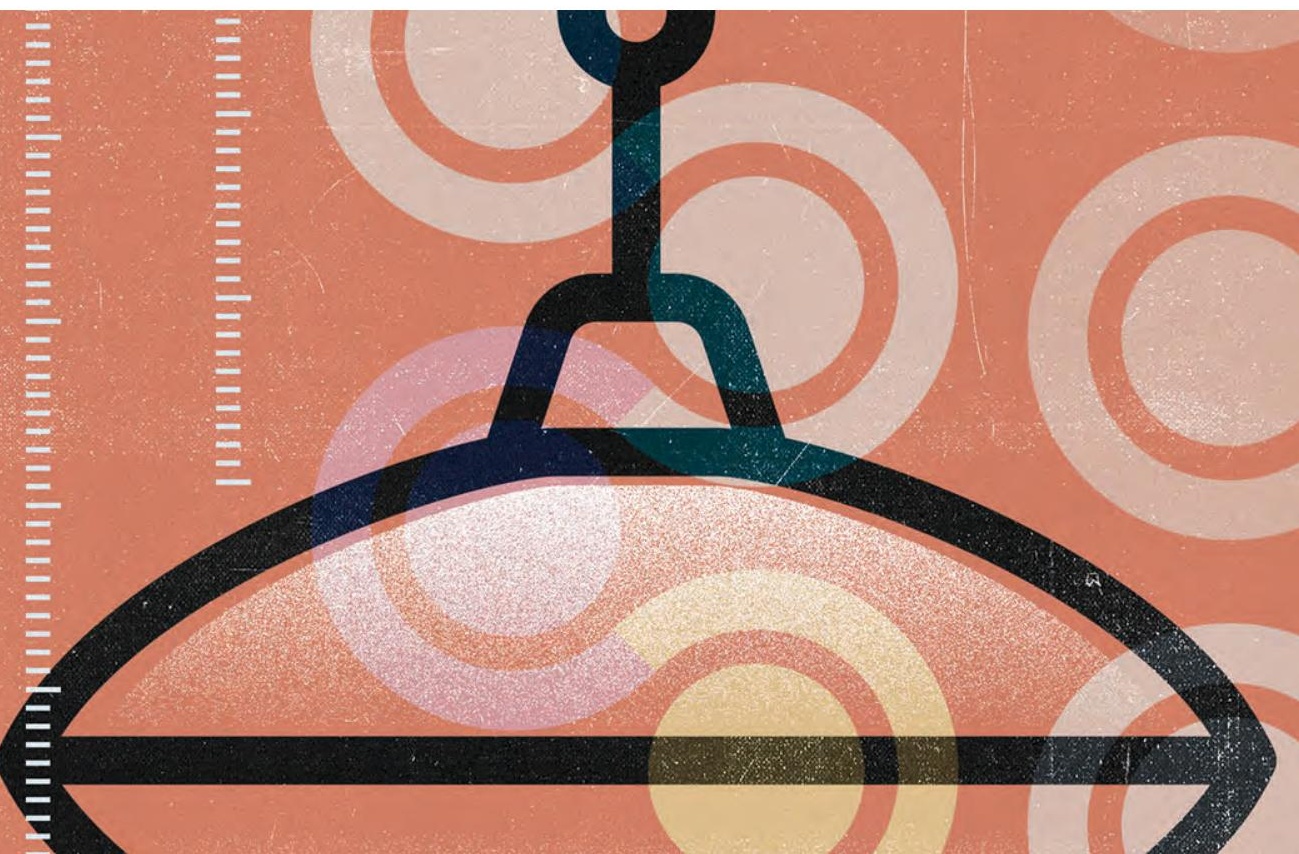


Como afirmado por diferentes autores, se os atores do setor privado percebem que uma determinada política é prejudicial para os seus interesses, os incentivos para participar da coalizão ou apoiar as políticas tendem a reduzir. Nesse sentido, Peiffer (2012) afirma que as coalizões precisam definir ganhadores e mostrar sucesso para poder ser sustentáveis no tempo. Falta, no entanto, uma classe empresarial que se considere como motor da necessária transformação do aparelho produtivo, com capacidade de arriscar.

A trajetória histórica indica que não há experiência de desenvolvimento capitalista sem Estado regulador e sem um empresariado schumpeteriano. Há, todavia, dois núcleos problemáticos. Em primeiro lugar, os estudos sobre Estado desenvolvimentista tendem a assumir uma certa convergência de ideias da classe política sobre os objetivos da política macroeconômica e setorial. Como analisam Whietfield \& Therkildsen (2011), a relação entre a elite governante e a oposição é estratégica. Para isso, deve se considerar a existência de oposição leal, o grau de fortaleza da elite para neutralizar à oposição, a centralização e coesão da elite e a capacidade de neutralizar ou atenuar atritos de diferentes tipos. Esse não é, como observamos, o caso do Brasil. Em segundo lugar, a literatura especializada não oferece uma resposta uníssona sobre como criar uma classe empresarial schumpeteriana. Entender os caminhos para articular ações e estratégias com um olhar próprio ao desenvolvimento nacional aparece como uma agenda de pesquisa a ser apronfundada.

\footnotetext{
Notas

' Esse artigo continua uma pesquisa do INCT-PPED em parceria com o IPEA e é uma versão reduzida e modificada do artigo publicado como Texto para Discussão 2098 do IPEA: Gaitán, Flavio \& Boschi, Renato (2015). Estado, Atores Predominantes e Coalizões para o Desenvolvimento. Brasil e Argentina em perspectiva comparada. Agradecemos a Carlos Henrique Santana a revisão do texto e as ótimas sugestôes analíticas. Também a Ana Carolina Oliveira pela revisão do texto.

${ }^{2}$ Em particular, a consolidação do pensamento neoconservador e a crise financeira de forte impacto na América Latina, logo após o aumento dos juros financeiros nos Estados Unidos, em 1979.

3 Diferentes visões sobre o Estado desenvolvimentista (Evans, 1996; Kholi, 2004) afirmam que o empresariado não foi um ator passivo e que as relações entre Estado e setor privado foram centrais para o desenho e implementação das estrategias de desenvolvimento. Há uma longa discussão na sociologia econômica sobre a necessidade dos empresários se organizarem para poder influenciar nas decisões públicas (Lissin, 2008). Sm importar a posicão sobre esse debate, há um relativo consenso sobre a mportância de contar com lideranças com capacidade de representar fidedignamente os diferentes interesses do setor privado (Brautigam, Rakner \& Taylor, 2002; Peiffer, 2012; Diniz \& Boschi, 2007; Diniz, 2010; Boschi, 2011).

${ }^{4}$ Cardoso foi Ministro de Fazenda do presidente Itamar Franco, responsável pelo plano Real. Em 1994 foi eleito presidente por uma coalizão de partidos que incluiam PSDB, PMDB, PFL e PTB.

${ }^{5}$ O PT foi em aliança com o PL, PMN e PCB.

${ }^{6}$ Reunião do Comitê de Política Monetária (Copom) n 81, 19 fev. 2003. Banco Central do Brasil. Histórico das Taxas de Juros.

7 Em setembro de 2003 diferentes centrais sindicais assinaram o documento "A Pauta do Crescimento" criticando o baixo crescimento e reclamando a ciação de postos de trabalho. Em 2004 a CUT, a CNI e a FIESP começaram a reclamar uma ampliação do Conselho Monetário Nacional de modo de incluir outros objetivos além da estabilidade macroenômica, em particular crescimento e emprego.
} 
${ }^{8}$ Em dezembro de 2003, final do primeiro ano de governo, foram expulsos quatro deputados do PT por votar contra a reforma da previdência impulsada pelo Poder Executivo: Heloísa Helena, Luciana Genro, João Batista Babó e João Fontes.

9 O presidente Lula foi reeleito em 2006 para o periodo 2007-2010, com o apóio de uma coalizão que incluia os seguintes partidos: PRB, PC do B, PMDB, PP, PR, PTB, PV, PDT, PAN, PSB, PCB. Para seu segundo mandato, Lula contou com apoio de uma coalizão de doze partidos (PT, PMDB, PRB, PCdoB, PSB, PP, PR, PTB, PV, PDT, PAN e PSC).

${ }^{10}$ A política macroeconômica defendida pela dupla Palocci-Meirelles era próxima da ortodoxia: uso de metas rígidas de inflação e superávit primário (Erber, 2011; Diniz \& Boschi, 2011).

11 Para mais informações ver: Sob Lula, setor produtivo bate o financeiro. Folha de São Paulo, 29 de agosto de 2005. Disponível em: http://www1.folha.uol.com.br/fsp/dinheiro/fi2908200515.htm.

${ }^{12}$ Para mais informações ver: Brasil Econômico, 27 dez. 2011, Crescimento do país é estimulado pelo consumo maior das famílias. Disponível em: <http://goo.gl/fLN4te>.

${ }^{13}$ Aumenta de 24.6\% do PIB em 2003 a 30.9\% em 2006. Essa relação entre crédito e PIB ficou em 35,2\%, em 2007, 40,8\%, em 2008, e em 45\% em 2009. Em novembro de 2010, chegou a 46,3\%, com saldo de R\$ 1,678 trilhão. Ver: http://memoria.ebc.com.br/agenciabrasil/noticia/2010-12-27/credito-bancario-temcrescimento-recorde-nos-oito-anos-do-governo-lula.

${ }^{14}$ Para mais informações ver: Carta Capital, 13 dez. 2013. No campo, a concentração das receitas é enorme. Disponível em: <http://goo.gl/oXCo1b>.

${ }^{15}$ Tribuna. 16/12/2003 CNA diz que 2016 foi um bom ano agrícola, mas não para todos. http://www. tribunapr.com.br/noticias/cna-diz-que-2003-foi-um-bom-ano-agricola-mas-nao-para-todos/

${ }^{16}$ Para mais informações ver: Carta Maior, 6 out. 2010, Criação de emprego. Disponível em: <http://goo. $\mathrm{gl} / \mathrm{tEb} 3 \mathrm{Ce}>$.

${ }_{17}$ Para mais informações ver: Banco Mundial, População Ativa. Disponível em: <http://goo.gl/mKRShD>.

18 Para mais informações ver: Cepalstat. Taxa de desemprego por sexo. Disponível em: <http://goo.gl/ eDovUo>.

${ }^{19}$ Em particular, o Programa Bolsa Família, criado por Lei n 10.836/2004 e regulamentado por Decreto n 5209/2004, que beneficia 13 milhões de famílias e 52 milhões de pessoas.

${ }^{20}$ Para mais informações ver: Cepalstat. Distribución del ingreso de las personas por deciles. Disponível em: <http://goo.gl/oKz5jR>.

${ }^{21}$ Ministra Chefe da Casa Civil apartir de 2006, Dilma Rousseff foi eleita presidenta por uma coalizão que incluia, junto ao PT, 8 partidos à esquerda e direita: PMDB, PR, PSB, PDT, PSC, PC do B, PRB, PTC.

22 Serrano \& Summa (2013) afirmam que a contração fiscal promovida em 2010 e 2011 impactou de forma negativa na demanda agregada e, consequentemente, sobre o crescimento.

${ }^{23}$ Para mais informações ver: Banco Central do Brasil. Histórico das Taxas de Juros. Disponível em: <http:// goo.gl/zZmUQd>.

24

${ }^{25}$ Esse ponto é ressaltado por Bresser-Pereira em várias entrevistas. Ver, por exemplo: http://brasileiros. com.br/2016/09/perdemos-ideia-de-nacao/. Accesso em: 10/05/2017.

${ }^{26}$ Confederação Nacional dos Trabalhadores nas Empresas de Crédito.

${ }^{27}$ As medidas provisórias 664 e 665 (posteriormente tranformadas em Leis) regularam um aumento do tempo necesário para ter direito ao seguro desemprego (de 6 para 12 meses), maiores requisitos par a pensão por morte e abono salarial (PIS) e também novo cálculo do auxílio doença.

${ }^{28}$ A desoneração da folha de pagamento foi instituída pela Lei 12.546/2011, e consiste na substituição da incidência da contribuição previdenciária patronal sobre folha de salários pela incidência sobre o faturamento. A Receita Federal é responsável por apurar a renúncia decorrente dessa medida, para fins do repasse do Tesouro ao Fundo do Regime Geral de Previdência Social, como forma de compensar as perdas com essa renúncia.

${ }^{29}$ Almeida, M. Blogo do Mansueto Almeida. O primeiro ano da nova matriz econômica, 21 de julho de 2015. In: https://mansueto.wordpress.com/2015/07/21/o-primeiro-ano-da-nova-matrizeconomica-2012/. Almeida, M. Blogo do Mansueto Almeida. A nova matriz econômica falhou. Também: A nova matriz econômica falhou 2. 11 de maio de 2014. In: https://mansueto.wordpress.com/2014/05/11/anova-matriz-economica-falhou-2/. Pessoa, S. Por que o governo embarcou na nova matriz econômica. Revista Conjuntra Econômica, v. 68, n. 9, setembro 2014, pp. 14-15. In: http://bibliotecadigital.fgv.br/ 
ojs/index.php/rce/article/viewFile/48015/45893. Schwartzman, A. Trivial Requentado. 2 de março de 2016. http://www.chumbogordo.com.br/5495-trivial-requentado/. Pessoa, S. Rescaldo da nova matriz econômica. Folha de São Paulo. 7 de junho de 2015. In: http://www1.folha.uol.com.br/colunas/ samuelpessoa/2015/06/1638639-rescaldo-da-nova-matriz-economica.shtml. O Globo. Arminio Fraga: Ajuste fiscal é insuficiente e tem problemas de qualidade, 8 de abril de 2016. . http://oglobo.globo.com/ economia/arminio-fraga-ajuste-fiscal-insuficiente-tem-problemas-de-qualidade-15816918. O Globo. A economia vive um momento de grave perigo, diz Arminio Fraga, 12 de março de 2014. http://oglobo. globo.com/economia/a-economia-vive-um-momento-de-grande-frustracao-grave-perigo-diz-arminiofraga-11857553. Pessoa, S. Asenção e queda da nova matriz econômica. Revista Conjuntra Econômica, v. 67, n. 11, setembro de 2013, p. 10-11. In: http://bibliotecadigital.fgv.br/ojs/index.php/rce/article/ view/21268/20017.

30 "O problema do Brasil é a dívida das empresas, diz economisa". Exame, 10 de outubro de 2016. Disponivel em: http://exame.abril.com.br/economia/para-economista-pec-troca-pneu-de-carro-commotor-fundido.

${ }^{31}$ Bruno \& Caffe (2014) afirmam que os detentores de títulos públicos federais estão distribuidos entre famílias (1\%), empresas não financeiras (entre 10 e 18\%), empresas financeiras (entre 1 e 5\%) e fundos de investimento.

32 O documento foi elaborado com base nos dados da declaração de Imposto de Renda de Pessoa Física (IRPF) fornecidos pela Receita Federal do Brasil (RFB). Em sua apresentação, a SPE-MINFAZ destacou que "Os números de 2014, declarados pelos contribuintes à RFB em 2015

${ }^{33}$ CNA decide apoiar movimento em favor do impeachment da presidente Dilma Rousseff. Noticias Agricolas, 6/4/2016. Disponível em: https://www.noticiasagricolas.com.br/noticias/politicaeconomia/171360-cna-decide-apoiar-movimento-em-favor-do-impeachment-da-presidente-dilmarousseff.html\#.WRn8VdLyvIU

${ }^{34}$ Ou governo muda ou melhor arrumar as malas, diz Paulo Skaf. Folha de São Paulo,2/12/2015. Disponível em: http://www1.folha.uol.com.br/mercado/2015/12/1714172-ou-governo-muda-ou-melhor-arrumaras-malas-diz-paulo-skaf.shtml. Acesso em: 12/05/2017.

${ }^{35}$ Em abril de 2016, a Câmara dos Deputados, com 367 votos favoráveis, 137 contrários, além de 7 abstenções e 2 ausentes, autorizou o Senado Federal a instaurar processo de impeachment contra Dilma. No mês seguinte, com 55 votos favoráveis, 22 contrários e 2 ausentes, o Senado Federal autorizou a abertura do processo de impeachment, e determinou o seu afastamento da Presidência da República pelo período de até 180 dias. Por fim, em agosto, o plenario do Senado decidiu afastar definitivamente a presidenta Rousseff por 61 votos a favor. Imediatamente, tomou posse o vicepresidente Temer.

36 "Pedalada fiscal" faz referência à prática de demorar o repasse de recursos para os bancos que devem processar as despessas do governo com o objetivo de melhorar as contas públicas.

${ }^{37}$ Não por amplamente analisado devemos deixar de mencionar que no debate na Câmara, não foram as referências às "pedaladas fiscais" as mais frequentes, mas palavras do tipo "família,",Deus","evangelho"e um sem-número de nomes dos familiares dos representantes. Sobre isto, consultar: http://www.sul21.com. br/jornal/grafico-mostra-os-motivos-alegados-nos-votos-de-deputados-para-o-impeachment.

${ }^{38}$ No período 2011-2015, a presidente contava com o apoio de 62 senadores, dos quais 55 consistentes; 19 na oposição. Já na Câmara, 351 deputados consistentes, 51 condicionados e apenas 111 da oposição (DIAP, 2010).

${ }^{39}$ Entre eles, Marta Suplicy, Edilson Lobato, Garibaldi Neves, Eduardo Braga (todos do PMDB), Fernando Bezerra (PSB), Aguilando Ribeiro (PP), Alfredo Nascimento (PR), Mauro Lopes (PMDB) e Eduardo Lopes (PRB).

${ }^{40}$ A gravação de uma conversa entre o Senador Romero Jucá (PSDB) e Sergio Machado, difundida por um canal de noticias, revela um otencial acordo de um setor da classe política para afastar à presidenta Roussef, como motivo para acabar com as pesquisas da operação Lava-Jato. A entrevista faz referência a "...um pacto nacional com o Supremo, com tudo...".

${ }^{41}$ Já com Michel Temer no governo, a CNI entregou um cnjunto de medidas para "superar a crise", incluindo ajuste fiscal, reformas na legislação trabalhista e redução do custo da burocracia para as empresas. 


\section{Bibliografía}

AMABLE, B. The Diversity of Modern Capitalism. Oxford: Oxford University Press, 2003.

AMSDEN, A. Asia's next giant: South Korea and late industrialization. New York: Oxford University Press, 2001.

BANCO MUNDIAL. World Development Report 1997. The State in a changing world, Washington DC: Banco Mundial, 1997

BANCO MUNDIAL. Informe sobre el Desarrollo Mundial 2002. Instituciones para los mercados, México DF: Mundi-Prensa, 2002.

BARBOSA, N. Dez anos de política econômica. In Sader, E. (org.). Dez anos de governos pósneoliberais no Brasil: Lula e Dilma. São Paulo: Boitempo, 2013.

BARBOSA, N. O desafio macroeconômico de 2015-2018. Revista de Economia Política, v. 35, n. 3, p. 403-425, julho setembro-2015.

BIELSCHOWSKY, R. Estratégia de desenvolvimento e as três frentes de expansão no Brasil: um desenho conceitual. Economia e Sociedade, Campinas, v. 21, número especial, p. 729-747, dezembro de 2012.

BICHIR, R. Capacidades Estatais Para a Implementação de Programas de Transferência de Renda: Os Casos de Brasil, Argentina e África do Sul, TD 2032, Brasília: IPEA, 2015.

BOITO Jr, A. A burguesia brasileira no governo Lula. XXVII Congreso de la Asociación Latinoamericana de Sociología. VIII Jornadas de Sociología de la Universidad de Buenos Aires. Asociación Latinoamericana de Sociología, Buenos Aires, 2009.

BOSCHI, R. Variedades de capitalismo, política e desenvolvimento na América Latina. Belo Horizonte: Editora UFMG, 2011.

BOSCHI, R.; GAITÁN, F. Intervencionismo estatal y políticas de desarrollo en América Latina. In: ENCONTRO DA ASSOCIAÇÃO BRASILEIRA DE CIÊNCIA POLÍTICA, 6., Campinas. Campinas: ABCP, 2008.

BOSCHI, R.; GAITÁN, F. Politics and development: lessons from Latin America. In: BOSCHI, R.; GAITÁN, F. Novo Desenvolvimentismo. In: LEAL IVO, A. (Org.). Dicionário Temático Desenvolvimento e Questão Social, Annablume, p. 325-329, 2013.

BÉRTOLA, L. \& OCAMPO, J. El Desarrollo Económico de América Latina desde la Independencia. México: FCE, 2012.

BRAUTIGAM, D., RAKNER, L., \& TAYLOR, S. Business Associations and Growth Coalitions in SubSaharan Africa. Journal of Modern African Studies, v. 40, n. 4, p. 519-547, 2002.

BRESSER-PEREIRA, L. C. Empresários, o governo do PT e o Desenvolvimentismo. Revista de Sociologia e Política, v. 21, n. 47, pp. 21-29, setembro de 2013. BRESSER-PEREIRA, L. C. Do antigo ao novo desenvolvimentismo na América Latina. FGV-SP Texto para Discussão n. 274, Novembro de 2010.

BRESSER-PEREIRA, L. C. "Estado y Mercado en el Nuevo Desarrollismo". Nueva Sociedad, n. 210, pp. 110-125, Julio-Agosto de 2007.

BRUNO, M. e CAFFE, R. Crecimiento, Distribuição e acumulação de capital numa economia financeirizada: uma análise dos limites estruturais ao desenvolvimento brasileiro. 30 ANPOCS, Outubro 2014.

CAGNIN, R., MAGALHÃES PRATES, D; DE FREITAS, M. C e NOVAIS, L. F. A gestão macroeconômica do governo Dilma (2011-2012). Novos Estudos n. 97, pp. 169-185. Novembro 2013. 
CEPAL (2012). Medidas de política implementadas en América Latina y el Caribe ante las adversidades de la economía internacional, 2008-2012. Santiago de Chile: Edición de las Naciones Unidas.

CEPAL (2010). La Hora de la Igualdad. Santiago de Chile: Edición de las Naciones Unidas. CEPAL (2016). Horizonte 2030: la igualdad en el centro del desarrollo sostenible. Santiago: Edición de las Naciones Unidas.

CONTEC. Lucros dos Bancos: síntese comparativa nos últimos três governos, Brasília: Contag, 2014.

COSTA PINTO, E.; GUEDES PINTO, J. P; BARULO, G.; SCHONERWAL, C. e NOGUEIRA. A economia política dos governos Dilma: acumulação, bloco de poder e crise. PD 004, Instituto de Economia UNICAMP, 2016.

DE PAULA, LUIZ FERNANDO; MODENESI, A. M.; PIRES, M. C. The tale of the contagion of two crises and policy responses in Brazil: a case of (Keynesian) policy coordination?, Journal of Post Keynesian Economics, v. 37, n. 3, pp. 408-435, 2015.

DE PAULA, L. F. "Repensando o Desenvolvimentismo”, en: São Paulo em Perspectiva, v. 20, n. 3, p. 47-58, julio-septembro de 2007.

DE PAULA, L. F. \& OREIRO, J. L. Novo Desenvolvimentismo e a Agenda de Reformas Econômicas para o crescimento sustentado com estabilidade de preços e equidade social, Texto preliminar para discusión, 2009.

DE TONI, J. 10 anos de política industrial: Balanço e perspectivas. Brasília: ABDI, 2015.

DI CAPRIO, A. Introduction: The Role of Elites in Economic Development. In: Alice H. Amsden, Alisa DiCaprio and James A. Robinson (eds.). The Role of Elites in Economic Development. Oxford: Oxford University Press, 2012.

DIAP. Radiografia do Novo Congresso. Legislatura 2011-2015. Apoio do Governo Dilma no Congresso. Brasília: Departamento Intersindical de Assessoria Parlamentar, 2010.

DINIZ, E. Empresário, estado e capitalismo no Brasil: 1930-1945. Rio de Janeiro: Paz e Terra, 1978.

DINIZ, E. Empresariado industrial, representação de interesses e ação política: trajetória histórica e novas configurações. Política e Sociedade, Florianópolis, v. 9, n. 17, outubro de 2010.

DINIZ, E.; BOSCHI, R. A difícil rota do desenvolvimento: empresários e a agenda pós-neoliberal. Belo Horizonte: Editora UMFG, 2007.

DINIZ, E. \& BOSCHI, R. Strategic elites and economic outlooks in Brazil, paper apresentado ao Congresso LASA, São Francisco, maio de 2011.

DINIZ, E. O Pós-Consenso de Washington: globalização, Estado e governabilidade reexaminados. In: Diniz, E. (org). Globalização, Estado e Desenvolvimento: Dilemas do Brasil no novo milênio. Rio de Janeiro: FGV, 2007.

DINIZ, E. \& GAITÁN, F. Repensando o Desenvolvimentismo: Estado, Instituições e a construção de uma agenda de desenvolvimento para o século XXI. Curitiba: Hucitec, 2016.

DOWBOR, L. Resgatando o potencial financeiro do Brasil. Outubro de 2015. In: http://dowbor. org/2016/08/ladislau-dowbor-resgatando-o-potencial-financeiro-do-pais-versao-atualizadaem-04082016-agosto-2016-47p.html/

DUVERGER, M. Os partidos políticos, Brasília: Editora da UNB, 1980.

EBENAU, M., BRUFF, I., MAY, C. (Eds.). New Directions in Comparative Capitalisms Research Critical and Global Perspectives. London: Palgrave Macmillan, 2015. 
ERBER, F. As Convenções sobre Desenvolvimento no Governo Lula: um ensaio de economia política. Revista de Economia Política, vol. 31, no 1 (121), pp. 31-55, janeiro-março de 2011.

EVANS, P. El Estado como problema y como solución. Desarrollo Económico, Buenos Aires, v. 35 , n. 140, p. 529-562, 1996.

EVANS, P.; RUESCHEMEYER, D.; SKOCPOL, T. (Eds.). Bringing the State back in. New York: Cambridge University Press, 1985.

FREITAS, ROGÉRIO. Exportações agropecuárias: Importância relativa e grupos de produto. Brasília: IPEA, 2012.

GAITAN, F. \& BOSCHI, R. (2015). Estado, Atores Predominantes e Coalizões para o Desenvolvimento: Brasil e Argentina em perspectiva comparada. Texto para Discussão 2098, Brasília: IPEA, 2015. GAITÁN, F. Auge, ocaso y resurgimiento de los estudios sobre desarrollo en América Latina. Documento de Proyecto LC/W 575, ILPES-CEPAL, 2014

GONÇALVES, R. Governo Lula e Nacional-desenvolvimentismo às avessas. Resita da Sociedade Brasileira de Economia Política, N. 31, pp. 5-30, 2012.

HALL, P. The political power of economic ideas: Keynesianism across nations. Princeton: Princeton University Press, 1989.

HANCKÉ, B.; RHODES, M.; THATCHER, M. Beyond varieties of capitalism: conflict, contradictions and complementarities in European economy. Oxford: Oxford University Press, 2007.

IANONI, M. Autonomia do Estado e desenvolvimento no capitalismo democrático. Revista de Economia Política, São Paulo, v. 33, n. 4, out./dez. 2013.

IANONI, M. Estado e coalizão desenvolvimentista no Brasil no ciclo pós-neoliberal. In: ENCONTRO DA ASSOCIAÇÃO BRASILEIRA DE CIÊNCIA POLÍTICA, 9. Brasília: ABCP, ago. 2014.

IPEA. Comunicado n. 155 A Década Inclusiva (2001-2011): Desigualdade, Pobreza e Políticas de Renda, 25 de setembro de 2012.

JOHNSON, C. MITI and the Japanese miracle. Stanford: Stanford University Press, 1982.

KHOLI, A. State directed development: political power and industrialization in the global periphery. Cambridge: Cambridge University Press, 2004.

LAWS, E. Political settlements, elite pacts, and governments of National Unity. Background paper 10, Developmental Leadership Program, 2012.

LEFTWICH, A.; HOGG, S. The case for leadership and the primacy of politics in building effective states, institutions and governance for sustainable growth and social development. Birmingham: Background Paper, n. 5. DLP, 2011.

LEFTWICH, A. "Bringing the Agency Back in: Politics and Human Agency in Building Institutions." DLP Research Paper 06, Synthesis and Overview Report of Phase One of the Leaders, Elites and Coalitions Research Programme, 2009.

LEFTWICH, A., \& LAWS, E. "Riker in the Tropics: The Theory of Political Coalitions (1962) and the Politics of Change in Developing Countries" Concept Paper 02, The Development Leadership Program, 2012.

LEFTWICH, A., \& WHEELER, C. "Politics, Leadership and Coalitions in Development: Findings, Insights and Guidance from the DLP's first Research and Policy Workshop, Frankfurt 10-11 March, 2011." Research and Policy Workshop Report, The Development Leadership Program, 2011.

LINDBLOM, C. The Market as prison. The Journal of Politics, v. 44, n. 2, pp. 324-336, 1982.

LINZ, J. J. La quiebra de las democracias. Madrid: Alianza, 1978. 
LISSIN, L. Acción Colectiva Empresaria. Homogeneidad dada o construida? Un análisis a la luz de las corporaciones empresariales en la crisis del 2001. IDAES. Documentos de Investigación Social № 3, 2008.

MELLO, G. Diagnóstico dos governos Dilma Rousseff: Do industrialismo à virada do neoliberalismo. XXI Encontro Nacional de Economia Política. Sociedade Brasileira de Economia Política. São Bernardo do Campo, 2016.

MINELLA, A. C. Maiores bancos privados no Brasil: um perfil econômico e sociopolítico. Sociologias, Porto Alegre, ano 9, no 18, pp. 100-125jul./dez. 2007.

MINISTERIO DE AGRICULTURA, PECUARIA E ABASTECIMENTO (MAP). Intercâmbio comercial do Agronegócio. Principais Mercados de Destino, 2012.

MORAES, W. Mudanças recentes na legislação trabalhista na América Latina em meio a continuidades: os casos de Brasil e Argentina. In: GAITAN, F.; DEL RIO, A. (Orgs.). Instituições, política e desenvolvimento: América Latina frente ao século XXI. Curitiba: CRV, 2013.

NOGUEIRA DA COSTA, F. In: Diniz, Eli \& Gaitán, Flavio. Repensando o Desenvolvimentismo: Estado, Instituições e a construção de uma agenda de desenvolvimento para o século XXI. Curitiba: Hucitec, 2016.

NOGUEIRA DA COSTA, F. O mapa da riqueza do Brasil, 2015. In: http://jornalggn.com.br/noticia/ o-mapa-da-riqueza-no-brasil-por-fernando-nogueira-da-costa.

OFFE, C. Work: the key sociological category. In: KEANE, J. (Ed.). Disorganized capitalism: contemporary transformations of work and politics. Cambridge: MIT Press, 1985.

PAES DE BARROS, R. Sobre a evolução recente da pobreza e a desigualdade no Brasil. Brasília: IPEA, 2009.

PALAZZO DIAZ, R. Organização e posicionamento político dos bancos no governo Lula. Dissertação de mestrado apresentada ao Instituto de Filosofia e Ciências Humanas da UNICAMP para obtenção do título de mestre em Ciência Política, 2012.

PEIFFER, C. Patterns and hypotheses from a survey of the literature. Concept Paper 03, Developmental Leadership Program, 2012.

PERISSINOTTO, R. O conceito de Estado desenvolvimentista e sua utilidade para os casos brasileiro e argentino. Revista de Sociologia e Política, v. 22, n. 52, 59-75, dezembro 2014.

PRZEWORSKI, A.; WALLERSTEIN, I. Structural dependence of the state on capital. American Political Science Review, v. 82, n. 1, p. 58-85, 1988.

RECEITA FEDERAL (2016). Desoneração da Folha de Pagamento. Disponível em: http://idg. receita.fazenda.gov.br/dados/receitadata/renuncia-fiscal/renuncia-fiscal-setorial

RODRIGUEZ, O. El Estructuralismo latinoamericano, México: Siglo XXI Editores, 2006.

SALLUM JR, B. O Brasil sob Cardoso, neoliberalismo e desenvolvimentismo.

Tempo Social, v. 11, n. 2, São Paulo, p.23-47, pp. 23-47, out. 1999.

SCHNEIDER, B.; MAXFIELD, S. Business, the State, and economic performance in developing countries. In:___. (Eds.). Business and the State in developing countries. Ithaca: Cornell University Press, 1997.

SCHUMPETER, J.-A. Capitalismo, socialismo e democracia. Rio de Janeiro: Zahar, 1984.

SERRANO, F.; SUMMA, R. "A desaceleração rudimentar da economia brasileira desde 2011". In: Earp, F. S.; Bastian, E.; Modenesi, A. M. Como vai o Brasil? Rio de Janeiro, 2013. 
SERRANO, F. \& SUMMA, R. Demanda agregada e a desaceleração do crescimento econômico brasileira de 2011 a 2014, Center for Economic Policy Research, agosto de 2015.

SICSÚ, J. \& MICHEL, R. Porque Novo Desenvolvimentismo. Jornal dos Economistas n. 186, pp. 3-5, janeiro 2005.

SINGER, A. Cutucando onças com varas curtas. O ensaio desenvolvimentista do primeiro mandato de Dilma Rousseff. Novos Estudos CEBRAP № 102, pp. 43-71, 2015.

SINGER, A. Os sentidos do lulismo. São Paulo: Companhia das Letras, 2012.

SOLIMANO, ANDRÉS \& AVANZINI, DIEGO. The international circulation of elites: knowledge, entrepeneurial and political. In: Amdsem, Alice, Alisa Di Caprio \& James Robinson (eds). The Role of elites in economic development. UNU-Wider e Oxford, 2012.

TANAKA, M. “En busca del eslabón perdido: coaliciones sociales y procesos políticos en el desarrollo territorial rural". Documento de Trabajo № 111. Programa Dinámicas Territoriales Rurales. Santiago de Chile: Rimisp, 2012.

TEIXEIRA, C. \& MONTANI MARTINS, N. Política fiscal e a desaceleração da economia brasileira no governo Dilma (2010-2012). Texto para Discussão 013/2013, Instituto de Economia da UFRJ.

VAN WYK, J. A. Cadres, Capitalists, Elites and Coalitions. The ANC, Business and Development in South Africa. The Nordic African Institute Discussion Paper № 46, 2009.

WADE, R. Governing the market: economic theory and the role of government in East Asian industrialization. Princeton: Princeton University Press, 1990.

WEISS, LINDA (ed.). States in the Global Economy. Bringing Domestic Institutions Back In. London: Cambridge University Press, 2003.

WOO, M. The Developmental State. Ithaca: Cornell University Press, 1999.

WHAITES, A (2008) "States in Development: Understanding State-Building", DfID Working Paper. London: DfID.

WHITFIELD, LINDSAY \& THERKILDSEN OLE. What Drives States to Support the Development of Productive Sectors? Strategies ruling elites pursue for political survival and their policy implications, DIIS (Danish Institute for International Studies) Working Paper, 2011: 15

ZALANGA, S. Ruling Elite Coalitions and State Bureaucratic Capacity: Accounting for Developmental and Predatory States in Malaysia and Nigeria. Mímeo, 2015.

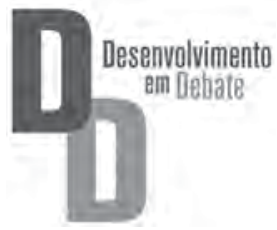

